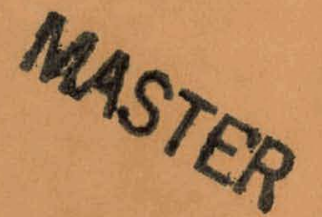

\title{
HIGH-TEMPERATURE WATER AND STEAM-CORROSION BEHAVIOR OF ZIRCONIUM-URANIUM ALLOYS
}

JULY 1959

CONTRACT AT-11-1-GEN-14

BETTIS PLANT-PITTSBURGH, PA. OPERATED FOR THE U.S. ATOMIC ENERGY COMMISSION BY BETTIS ATOMIC POWER DIVISION, WESTINGHOUSE ELECTRIC CORPORATION 


\section{DISCLAIMER}

This report was prepared as an account of work sponsored by an agency of the United States Government. Neither the United States Government nor any agency Thereof, nor any of their employees, makes any warranty, express or implied, or assumes any legal liability or responsibility for the accuracy, completeness, or usefulness of any information, apparatus, product, or process disclosed, or represents that its use would not infringe privately owned rights. Reference herein to any specific commercial product, process, or service by trade name, trademark, manufacturer, or otherwise does not necessarily constitute or imply its endorsement, recommendation, or favoring by the United States Government or any agency thereof. The views and opinions of authors expressed herein do not necessarily state or reflect those of the United States Government or any agency thereof. 


\section{DISCLAIMER}

Portions of this document may be illegible in electronic image products. Images are produced from the best available original document. 


\title{
HIGH-TEMPERATURE WATER AND STEAM-CORROSION BEHAVIOR OF ZIRCONIUM-URANIUM ALLOYS
}

\author{
Stanley Kass \\ Contract AT-11-1-GEN-14 \\ July 1959 \\ Price $\$ .75$ \\ Available from the Office of Technical Services, \\ Department of Commerce, \\ Washington 25, D. C.
}

\section{NOTE-}

This document is an interim memorandum prepared primarily for internal reference and does not represent a final expression of the opinion of Westinghouse. When this memorandum is distributed externally, it is with the express understanding that Westinghouse makes no representation as to completeness, accuracy, or usability of information contained therein.

\author{
BETTIS PLANT - PITTSBURGH, PA. \\ OPERATED FOR THE U.S. ATOMIC ENERGY COMMISSION BY \\ BETTIS ATOMIC POWER DIVISION, WESTINGHOUSE ELECTRIC CORPORATION
}


This report was prepared as an account of Government sponsored work. Neither the United States, nor the Commission, nor any person acting on behalf of the Commission:

A. Makes any warranty or representation, expressed or implied, with respect to the accuracy, completeness, or usefulness of the information contained in this report, or that the use of any information, apparatus, method, or process disclosed in this report may not infringe privately owned rights; or

8. Assumes any liabilities wlth pespect to tliu ust ur, ur lui daiilayes resulting from the use of any information, apparatus, method, or process disclosed in this report.

As used in the above, "person acting on behalf of the Commission" includes any cmploye or contractor of the Commission, or employe of such contractor, to the extent that such employe or contractor of the commissioul, ur empluge of such cantractor preperos, dicouml. nates, or provides access to, any information pursuant to his employment or contract with the Commission, or his employment with such contractor. 


\section{CONTENTS}

EXPERIMENTAL PROCEDURES

Page No.

Ingot Fabrication

Heat Treatment

Sample Preparation

Test Conditions

EXPERIMENTAL RESULTS

Zirconium $+10 \mathrm{w} / \mathrm{o}$ Uranium Alloys

Zirconium $+15 \mathrm{w} /$ o Uranium Alloys

Zirconium $+20 \mathrm{w} / \mathrm{o}$ Uranium Alloys

Zirconium $+35 \mathrm{w} /$ o Uranium Alloys

Zirconium $+50 \mathrm{w} / \mathrm{o}$ Uranium Alloys

Zirconium $+60 \mathrm{w} / 0$ Uranium Alloys

SUMMARY

DISCUSSION OF CORROSION BEHAVIOR

Zirconium +10 to $35 \mathrm{w} /$ o Uranium Alloys

Zirconium $+50 \mathrm{w} / \mathrm{o}$ Uranium Alloys

Zirconium $+60 \mathrm{w} / \mathrm{o}$ Uranium Alloys

REFERENCES

ILLUSTRATIONS

1 


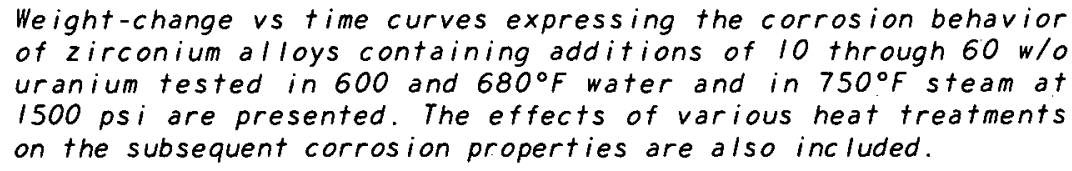

HIGH -TEMPERATURE WATER AND STEAM-CORROSION BEHAVIOR OF ZIRCONIUM-URANIUM ALLOYS

Stanley Kass

This report is a summary of all relevant available data describing the corrosion of zirconium alloys containing 10 to $60 \mathrm{w} / 0$ uranium in high-temperature water and steam, as well as the effects of heat treatment on the corrosion resistance.

TABLE I

\section{ZIRCONIUM ALLOYS INCLUDED} IN THE PROGRAM

\begin{tabular}{c} 
Ingot No. \\
\hline 014 \\
054 \\
028 \\
$\mathrm{~J}-777$ \\
056 \\
$\mathrm{~J}-499$ \\
$\mathrm{~J}-742$ \\
$\mathrm{E}-374$ \\
032 \\
420 \\
398 \\
138 \\
062 \\
\hline * actual \\
* nominal.
\end{tabular}

Comprehensive studies to evaluate the corrosion behavior of zirconium-uranium alloys in pres surized, high-temperature water and steam were conducted at the Bettis Atomic Power Division and other installations because these alloys represent potential fuel materials for water-cooled and moderated nuclear reactors. Reports summarizing the results of the studies have been issued (Refs 1, 2, and 3); however, the detailed data describing the effects of heat-treatment and uranium content have not been included in these previous reports.

\section{EXPERIMENTAL PROCEDURES}

Ingot Fabrication

Fifteen-, twenty-, and fifty-lb ingots were prepared from sponge zirconium and derby uranium, using conventional double-arc melting procedures in an argon atmosphere. The ingots were then forged at $1850^{\circ} \mathrm{F}$ and rolled at $1450^{\circ} \mathrm{F}$ to 0.150 -in. strip. Table I lists the nominal and actual compo-sitions of the alloys studied. 
Heat treatments, summarized in Table II, were performed in sealed, evacuated Vycor bulbs. The bulbs for the high-temperature treatments were evacuated to less than 0.03 micron, then, helium at $25 \mathrm{~cm} \mathrm{Hg}$ pressure was added.

TABLE II

LIST OF HEAT TREATMENTS STUDIED

\begin{tabular}{c}
$\begin{array}{c}\text { Heat } \\
\text { Treatment } \\
\text { No. }\end{array}$ \\
\hline 1 \\
$2 \mathrm{a}$ \\
$2 \mathrm{~b}$ \\
$2 \mathrm{c}$ \\
3 \\
4 \\
$5 \mathrm{a}$ \\
$5 \mathrm{~b}$ \\
$6 \mathrm{a}$ \\
$6 \mathrm{~b}$ \\
$6 \mathrm{c}$ \\
$6 \mathrm{~d}$ \\
$7 \mathrm{a}$ \\
$7 \mathrm{~b}$ \\
$7 \mathrm{c}$ \\
8 \\
$9 \mathrm{a}$ \\
$9 \mathrm{~b}$ \\
$9 \mathrm{c}$
\end{tabular}

$4 \mathrm{hr}$ at $800^{\circ} \mathrm{C}$, air cooled, then $4 \mathrm{hr}$ at $620^{\circ} \mathrm{C}$, furnace cooled

$4 \mathrm{hr}$ at $850^{\circ} \mathrm{C}$, water quenched

$4 \mathrm{hr}$ at $900^{\circ} \mathrm{C}$, water quenched

$4 \mathrm{hr}$ at $1000^{\circ} \mathrm{C}$, water quenched

$4 \mathrm{hr}$ at $850^{\circ} \mathrm{C}$, furnace cooled

$4 \mathrm{hr}$ at $650^{\circ} \mathrm{C}$, water quenched

$24 \mathrm{hr}$ at $575^{\circ} \mathrm{C}$, furnace cooled

$4 \mathrm{hr}$ at $575^{\circ} \mathrm{C}$, water quenched

$4 \mathrm{hr}$ at $850^{\circ} \mathrm{C}$, water quenched, then $1 \mathrm{hr}$ at $575^{\circ} \mathrm{C}$, furnace cooled

$4 \mathrm{hr}$ at $850^{\circ} \mathrm{C}$, water quenched, then $10 \mathrm{hr}$ at $575^{\circ} \mathrm{C}$, furnace cooled

$4 \mathrm{hr}$ at $850^{\circ} \mathrm{C}$, water quenched, then $30 \mathrm{hr}$ at $575^{\circ} \mathrm{C}$, furnace cooled

$4 \mathrm{hr}$ at $850^{\circ} \mathrm{C}$, water quenched, then $100 \mathrm{hr}$ at $575^{\circ} \mathrm{C}$, furnace cooled

$4 \mathrm{hr}$ at $850^{\circ} \mathrm{C}$, water quenched, then 1 week at $360^{\circ} \mathrm{C}$, furnace cooled

$4 \mathrm{hr}$ at $850^{\circ} \mathrm{C}$, water quenched, then 3 weeks at $360^{\circ} \mathrm{C}$, furnace cooled

$4 \mathrm{hr}$ at $850^{\circ} \mathrm{C}$, water quenched, then 5 weeks at $360^{\circ} \mathrm{C}$, furnace cooled

As =fabricated

$4 \mathrm{hr}$ at $850^{\circ} \mathrm{C}$, water quenched, then l week at $400^{\circ} \mathrm{C}$, furnace cooled

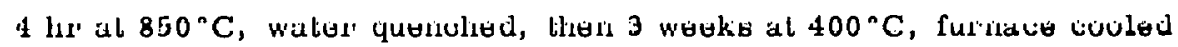

$4 \mathrm{hr}$ at $850^{\circ} \mathrm{C}$, water quenched, then 5 weeks at $400^{\circ} \mathrm{C}$, furnace cooled

\section{Sample Preparation}

Specimens 1 -in. $x$ 0.5-in. x 0.1-in. were machined to a $63 \mu$ in. rms finish from the 0.150-in. thick heat treated hot-rolled strip. Before testing, the specimens were lightly abraded to remove any surface, contamination brought about by the heat treatment, washed in Alconox, rinsed thirty minutes in tap water, rinsed in ethyl alcohol, and dried.

Test Conditions

Four specimens representing each heat treatment were exposed under static conditions to $316^{\circ} \mathrm{C}\left(600^{\circ} \mathrm{F}\right)$ or $360^{\circ} \mathrm{C}\left(680^{\circ} \mathrm{F}\right)$ water at saturation pressure, or in $400^{\circ} \mathrm{C}\left(750^{\circ} \mathrm{F}\right) \mathrm{steam} \mathrm{at} 1500^{\circ} \mathrm{psi}$ in externally heated, $1800 \mathrm{-ml}$ capacity, AISI Type $347 \mathrm{stainless} \mathrm{steel} \mathrm{autoclaves.} \mathrm{Temperature} \mathrm{con-}$ trol was maintained at $\pm 5^{\circ} \mathrm{F}$. The test water was passed through a mixed bed demineralizer to give a specific resistivity of greater than $500,000 \mathrm{ohm}-\mathrm{cm}$. The autoclaves were filled with sufficient water to give a $20 \%$ vapor space at temperature. The number of specimens tested in the autoclave was adjusted to insure complete immersion. The water in the 316 and $360^{\circ} \mathrm{C}$ tests was degassed by venting the autoclaves for short periods at a temperature between 100 and $150^{\circ} \mathrm{C}$. The autoclaves 
used for the $400^{\circ} \mathrm{C}$ steam tests were initially vented to maintain $1500 \mathrm{psi}$. The specimens were supported on stainless steel wire-mesh trays and did not rest upon one another, nor were they electrically insulated from each other or the autoclave. After each test period, the specimens were scrubbed with a soft brush to remove all loose oxide and were weighed to the nearest $0.2 \mathrm{mg}$.

\section{EXPERIMENTAL RESULTS}

The corrosion behavior is presented in terms of weight change per unit area during corrosion testing as a function of time in test for each alloy at each test temperature. The several heat treatments for each given alloy are compared. It should be noted that the weight change for these alloys is generally a weight loss, and the experimental points can best be fitted by straight lines. Thus, equations of the form $w=k t$ can be written to represent the relationship between weight loss and time. Rate constants were calculated from the graphically determined slopes and were plotted as a function of uranium content for a given temperature. The effect of temperature on the rate constants was determined by plotting the logarithm of the rate constant as a function of the reciprocal of the absolute temperature.

Zirconium $+10 \mathrm{w} / \mathrm{o}$ Uranium Alloys

The $360^{\circ} \mathrm{C}\left(680^{\circ} \mathrm{F}\right)$ water corrosion behavior of the zirconium $+10 \mathrm{w} / \mathrm{o}$ uranium alloys is shown in Figs. 1, 2, 3, and 4, where the weight change is plotted as a function of time for each of the various heat treatments studied.

The effect of quenching temperature on the resultant $360^{\circ} \mathrm{C}$ water corrosion of the $10 \mathrm{w} / \mathrm{o}$ uranium alloys is evident in Fig. 1. Specimens quenched from 850, 900, and $1000^{\circ} \mathrm{C}$ exhibited the optimum corrosion resistance. The oxide films produced were thin and adherent throughout the test. In contrast, the specimens quenched from 575 and $650^{\circ} \mathrm{C}$ initially produced adherent oxide films; however, film breakdown occurred within 7 days of exposure, followed by general spalling. It should be noted in Fig. 1 that the specimens quenched from $575^{\circ} \mathrm{C}$ exhibited lower corrosion-loss rates and weight changes than those quenched from $650^{\circ} \mathrm{C}$.

The effects of annealing temperature are shown in Fig. 2. The as-fabricated specimens, and specimens annealed at $575^{\circ} \mathrm{C}$ and slow cooled, exhibited similar corrosion behavior; the films were initially adherent, then slowly spalled. Specimens furnace-cooled from $850^{\circ} \mathrm{C}$ revealed lower corrosion resistance, while those air-cooled from $800^{\circ} \mathrm{C}$, reannealed at $620^{\circ} \mathrm{C}$, and furnace cooled, exhibited the least resistance. A comparison of the curves in Figs. 1 and 2 shows that the corrosion resistance of the specimens which were heated at $575^{\circ} \mathrm{C}$ is independent of cooling rate.

Figure 3, which depicts the $360^{\circ} \mathrm{C}$ water corrosion resistance of specimens quenched from $850^{\circ} \mathrm{C}$ and subsequently aged for $1,10,30$, and $100 \mathrm{hr}$ at $575^{\circ} \mathrm{C}$ and slow cooled, shows that a marked decrease in the corrosion resistance is brought about by aging at $575^{\circ} \mathrm{C}$. The aged specimens exhibited spalling after 7 days of exposure, and the corrosion rate increased with increasing annealing time. It should be noted that the specimens quenched from the beta region and aged at $575^{\circ} \mathrm{C}$ for 30 and $100 \mathrm{hr}$ (Fig. 3) corroded more rapidly than the samples annealed at $575^{\circ} \mathrm{C}$ for $4 \mathrm{hr}$ and quenched (Fig. 1) or for $24 \mathrm{hr}$ and furnace-cooled (Fig. 2).

Aging the $850^{\circ} \mathrm{C}$ quenched specimens at $360^{\circ} \mathrm{C}\left(680^{\circ} \mathrm{F}\right)$ (the corrosion test temperature) resulted in a very slight increase in the corrosion rate; however, no further decrease in corrosion resistance was observed when the aging time was increased from one to five weeks (Fig. 4). The oxide films produced were adherent throughout the test (approximately 180 days). The significant feature is that the samples were still gaining weight.

* Changes in area as a result of metal loss from corrosion were not factored into the calculations. ** All figures are found at the end of this report. 
The effect of test temperature on the corrosion behavior of the $10 \mathrm{w} / \mathrm{o}$ uranium alloy samples, slow cooled from $575^{\circ} \mathrm{C}$, is shown in Fig. 5. The corrosion rates vary from $-0.017 \mathrm{mg} / \mathrm{cm}^{2}-\mathrm{hr}$ at $316^{\circ} \mathrm{C}$ to $-0.025 \mathrm{mg} / \mathrm{cm}^{2}-\mathrm{hr}$ at $360^{\circ} \mathrm{C}$ and $0.046 \mathrm{mg} / \mathrm{cm}^{2}-\mathrm{hr}$ at $400^{\circ} \mathrm{C}$.

Zirconium $+15 \mathrm{w} / 0$ Uranium Alloys

In general, the behavior of the $15 \mathrm{w} / \mathrm{o}$ uranium alloys in water was very similar to the behavior of the $10 \mathrm{w} / 0$ alloys.

Quenching from the high temperature phase $\left(850\right.$ to $\left.1000^{\circ} \mathrm{C}\right)$ resulted in maximum corrosion resistance and adherent oxide films. Quenching from 575 and $650^{\circ} \mathrm{C}$ resulted in weight losses (nonadherent oxides) and decreased corrosion resistance (Fig. 6).

The corrosion resistance of material, slow cooled from the heat treating temperature (Fig. 7), decreased as the annealing temperature increased. Furthermore, the behavior of the specimens heat treated at $575^{\circ} \mathrm{C}$ was not influenced by cooling rate from the heat treating temperature (Figs. 6 and 7$)$.

Aging the high temperature $\left(850^{\circ} \mathrm{C}\right)$ quenched specimens at $575^{\circ} \mathrm{C}$, and cooling slowly, produced deleterious effects upon the corrosion resistance (F1g. 8). Whlle lle as-quinched specimeno ohowod adherent oxides throughout the test, specimens aged at $575^{\circ} \mathrm{C}$ and furnace cooled exhibited early spalling. The specimens held at $575^{\circ} \mathrm{C}$ for 10,30 , and $100 \mathrm{hr}$ corroded more rapidly than those aged for 1 hour.

The effect of aging at the corrosion test temperature $\left(360^{\circ} \mathrm{C}\right)$ on the corrosion behavior of $850^{\circ} \mathrm{C}$ quenched specimens is illustrated in Fig. 9. Slightly lower weight gains were obtained from the aged specimens throughout this test (210 days); however, it is difficult to state whether the lower weight gains reflected slight spalling, variations in weight change measurement, or improved resistance enhanced by the treatment.

Figure 10 shows the effect of temperature on the corrosion behavior of specimens slowly cooled from $575^{\circ} \mathrm{C}$. The water tested specimens exhibited weight losses throughout the test; huwever, the specimens tested in $400^{\circ} \mathrm{C}$ steam exhibited weight gains after 7 days of exposure, then spalled. The corrosion rate increased from -0.022 to -0.048 to $-0.982 \mathrm{mg} / \mathrm{cm}^{2}-\mathrm{hr}$ as the temperature increased from 316 to 360 to $400^{\circ} \mathrm{C}$, respectively.

Zireonium $120 \mathrm{w} / \mathrm{O}$ Urạnium Alloys

The effect of quenching temperature on the water corrosion behavior of the zirconium $+20 \mathrm{w} / \mathrm{o}$ uranium alloys is illustrated in Fig. 11. Quenching from the high temperature $\left(850\right.$ to $\left.1000^{\circ} \mathrm{C}\right)$ resulted in adherent oxide fllms and weight gains, while quenching from 575 and $650^{\circ} \mathrm{C}$ resulted in spalling oxides and weight losses. For the gamma quenched material, increasing the quenching temperature from 850 to $1000^{\circ} \mathrm{C}$ decreased the corrosion resistance.

Slow cooling after heat treating resulted in non-corrosion resistant forms of the alloys (Fig. 12 ). All specimens spalled within very short exposure times. Gamma $\left(850^{\circ} \mathrm{C}\right)$ quenched specimens, subsequently aged for $1,10,30$, and $100 \mathrm{hr}$ at $575^{\circ} \mathrm{C}$ and slow cooled, resulted in impaired corrosion resistance (Fig. 13). All aged specimens exhibited spalling, oxide films, and weight losses. The specimens aged for 10,30 , and $100 \mathrm{hr}$ revealed higher weight losses than those specimens aged for 1 hour.

The corrosion behavior of samples, gamma quenched and subsequently annealed for 1,3, and 5 weeks at $360^{\circ} \mathrm{C}\left(680^{\circ} \mathrm{F}\right)$, is shown in Fig. 14 and illustrates that adherent films were obtained. Specimens aged for 3 and 5 weeks show lower weight gain values than the specimens aged for 1 week.

Specimens furnace cooled from $575^{\circ} \mathrm{C}$ and subsequently tested in $400^{\circ} \mathrm{C}\left(750^{\circ} \mathrm{F}\right)$ steam exhibited weight gains at the onset of corrosion, then spalled rapidly, resulting in high weight losses (Fig. 15). 
The corrosion rate also increased from -0.029 to -0.066 to $-0.162 \mathrm{mg} / \mathrm{cm}^{2}-\mathrm{hr}$ as the test temperature was increased from 316 to 360 to $400^{\circ} \mathrm{C}$.

Zirconium $+35 \mathrm{w} / \mathrm{o}$ Uranium Alloys

Alloys containing $35 \mathrm{w} / \mathrm{o}$ or greater uranium exhibited markedly different behavior in water than was observed for the lower uranium alloys. The corrosion of the $35 \mathrm{w} / \mathrm{o}$ alloy was relatively insensitive to prior thermal history (although some differences were observed) and exhibited an early breakdown of the oxide film, resulting in general spalling. Specimens quenched from 575 and $850^{\circ} \mathrm{C}$ exhibited similar corrosion properties, while those quenched from 650 and $900^{\circ} \mathrm{C}$ exhibited slightly higher weight losses (Fig. 16). No difference in the corrosion behavior was noted for specimens slow cooled from the high or low temperatures (Fig. 17). It should be further noted that the slow cooled material corroded in a manner similar to the 650 and $900^{\circ} \mathrm{C}$ quenched material. Aging the as-quenched specimens at $575^{\circ} \mathrm{C}$ resulted in slightly lower corrosion resistance (Fig. 18); while aging at $360^{\circ} \mathrm{C}$ brought about very slight changes in the weight losses (Fig. 19).

The effect of corrosion test temperature (illustrated in Fig. 20) shows the increase in corrosion rate from -0.050 to -0.150 to $-0.264 \mathrm{mg} / \mathrm{cm}^{2}-\mathrm{hr}$ as the test temperature was increased from 316 to 360 to $400^{\circ} \mathrm{C}$.

Zirconium + $50 \mathrm{w} / \mathrm{o}$ Uranium Alloys

The corrosion behavior of the $50 \mathrm{w} / 0$ uranium alloy is summarized in Figs. 21, 22, 23, and 24, showing that the corrosion rate was relatively insensitive to thermal treatment and cooling rate. Furthermore, the corrosion resistance of the material quenched from $850^{\circ} \mathrm{C}$ was not altered by aging at 360,400 , or $575^{\circ} \mathrm{C}$.

The corrosion rates of the alloys increased with increasing test temperature (Fig. 25). The rate increased from -0.083 to -0.25 to $-0.80 \mathrm{mg} / \mathrm{cm}^{2}-\mathrm{hr}$ as the temperature increased from 316 to 360 to $400^{\circ} \mathrm{C}$.

Zirconium $+60 \mathrm{w} / 0$ Uranium Alloys

The corrosion resistance of the zirconium alloys containing approximately $60 \mathrm{w} / 0$ or more uranium differed from that of 35 and $50 \mathrm{w} / 0$ alloys. The corrosion was markedly affected by heat treatment. After appropriate heat treatments, the corrosion process was characterized by slow general corrosion followed by very rapid, accelerated corrosion and disintegration. Other heat treatments resulted in higher general corrosion and spalling without disintegration.

Figure 26 depicts the water corrosion behavior of specimens quenched from 575, 650, 850, 900 , and $1000^{\circ} \mathrm{C}$. Specimens quenched from $850^{\circ} \mathrm{C}$ or higher disintegrated within 9 days of exposure. The corrosion life (time for complete disintegration) increased as the quenching temperature was decreased from 800 to 650 to $575^{\circ} \mathrm{C}$. Furthermore, the corrosion rate of the $650^{\circ} \mathrm{C}$ quenched specimens prior to disintegration was approximately $40 \%$ of that obtained when the specimens were quenched from $575^{\circ} \mathrm{C}$.

Slow cooling after heating in the temperature range from 575 to $1000^{\circ} \mathrm{C}$ (Fig. 27) resulted in lower corrosion rates and longer lives than whon the material was rapidly cooled.

Aging the $850^{\circ} \mathrm{C}$ quenched specimens at $575^{\circ} \mathrm{C}$ dramatically increased the corrosion life. The corrosion resistance, however, decreased with increasing aging time. Specimens aged 1, 10,30 , and $100 \mathrm{hr}$ exhibited corrosion lives of 93,93,93, and 65 days respectively, in comparison to 3 days for unaged specimens. It was also observed that maximum corrosion resistance was obtained when $\mathrm{l}-\mathrm{hr}, 575^{\circ} \mathrm{C}$ aging was employed (see Fig. 28).

Aging at 360 and $400^{\circ} \mathrm{C}$ also markedly affected the corrosion behavior of the quenched samples (Figs. 29 and 30 ). Specimens aged for 1 week at $360^{\circ} \mathrm{C}$ had lives of 58 days, while those aged for 
3 and 5 weeks had 100 -day lives. A one- or three-week age at $400^{\circ} \mathrm{C}$ produced specimens which did not exhibit disintegration within 100 days of exposure; however, specimens aged for 5 weeks at $400^{\circ} \mathrm{C}$ disintegrated within 60 days of test.

The corrosion rate vs test temperature relationship for $60 \mathrm{w} / \mathrm{o}$ uranium alloys, slow cooled from $575^{\circ} \mathrm{C}$, is shown in Fig. 31. It should be noted that the specimens tested in $400^{\circ} \mathrm{F}$ steam were completely corroded within 15 days of test.

\section{SUMMARY}

Figures 1-31 demonstrate that the corrosion behavior of the alloys can be characterized empirically by equations of the form $w^{\prime}=k t$ for each heat treatment and test temperature. The graphically determined rate constants for the alloys in $360^{\circ} \mathrm{C}$ water are shown in Table III and graphically presented in Fig. 32. Figure 32 shows that:

1) For gamma quenched material, the corrosion rate increases slowly as the uranium content of the alloy is increased from 10 to $50 \mathrm{w} / \mathrm{o}$.

2) Similar behavior is noted for other heat treatments except for the $850^{\circ} \mathrm{C}$ furnace cooled material.

3) The specimens furnace cooled from $850^{\circ} \mathrm{C}$ show a linear relationship between corrosion rate and uranium content over the entire range of the alloys studied.

TABLE III

$316^{\circ} \mathrm{C}\left(680^{\circ} \mathrm{F}\right)$ CORROSION RATES OF ZIRCONIUM-URANIUM ALLOYS

\begin{tabular}{|c|c|c|c|c|c|c|c|}
\hline \multirow[b]{2}{*}{ Heat Treatment } & \multicolumn{7}{|c|}{$\begin{array}{l}\text { Corrosion Rate } \\
\left(\mathrm{mg} / \mathrm{cm}^{2}-\mathrm{hr}\right)\end{array}$} \\
\hline & $10 \mathrm{w} / 0 \mathrm{U}$ & $15 \mathrm{w} / 0 \mathrm{U}$ & $20 \mathrm{w} / \mathrm{o} \mathrm{U}$ & $35 \mathrm{w} / \mathrm{oU}$ & $40 \mathrm{w} / 0 \mathrm{U}$ & $50 \mathrm{w} / \mathrm{O} \mathrm{U}$ & $60 \mathrm{w} / 0 \mathrm{U}$ \\
\hline 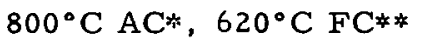 & -0.05 & -0.07 & -0.08 & -0.15 & -0.18 & -0.27 & -0.67 \\
\hline $850^{\circ} \mathrm{C}$, Quenched & +0.001 & +0.007 & +0.01 & -0.11 & -0.16 & -0.24 & $\mathrm{~F}^{\dagger}$ \\
\hline $900^{\circ} \mathrm{C}$, Quenched & +0.001 & +0.006 & +0.01 & -0.15 & -0.16 & -0.24 & $\mathrm{~F}^{\dagger}$ \\
\hline $1000^{\circ} \mathrm{C}$, Quenched & $+0,001$ & +0.005 & +0.01 & -- & -0.15 & -0.24 & $\mathrm{Ft}$ \\
\hline $850^{\circ} \mathrm{C}, \mathrm{FC}$ & -0.01 & -0.06 & -0.08 & -11.15 & $-\dot{0} .17$ & -0.26 & $=0.33$ \\
\hline $650^{\circ} \mathrm{C}$, Quenclied & .0 .0 .1 & $=0.07$ & -0.03 & .0 .11 & -0.18 & $=0 \%: 25$ & -0.63 \\
\hline $575^{\circ} \mathrm{C}, \mathrm{FC}$ & -0.03 & -0.05 & -0.07 & -0.15 & -0.19 & -0.28 & -0.93 \\
\hline $575^{\circ} \mathrm{C}, \cdot$ Quenched & -0.03 & -0.05 & -0.05 & -0.16 & -0.19 & -0.27 & -1.03 \\
\hline $\begin{array}{l}850^{\circ} \mathrm{C}, \text { Quenched, }+1 \mathrm{hr} \\
\text { at } 575^{\circ} \mathrm{C}, \mathrm{FC}\end{array}$ & -0.02 & -0.06 & -0.06 & -0.13 & -0.16 & -0.25 & -0.32 \\
\hline$+10 \mathrm{hr}$ at $575^{\circ} \mathrm{C}, \mathrm{FC}$ & -0.03 & -0.06 & -0.07 & -0.16 & -0.17 & -0.25 & -0.42 \\
\hline$+90 \mathrm{hl}$ al $575^{n} \mathrm{C}, \mathrm{TC}$ & 0.04 & -0.06 & $-\cap . \cap 7$ & -0.17 & -0.17 & $-0,25$ & -0.45 \\
\hline$+100 \mathrm{hr}$ at $575^{\circ} \mathrm{C}, \mathrm{FC}$ & -0.04 & -0.06 & -0.07 & -0.16 & -0.16 & -0.25 & -0.65 \\
\hline+1 week at $360^{\circ} \mathrm{C}, \mathrm{F}^{\prime} \mathrm{C}$ & +0.002 & +0.006 & $\neq 0.01$ & -- & -0.15 & -0.24 & -0.38 \\
\hline +3 weeks at $360^{\circ} \mathrm{C}$, & +0.002 & $\neq 0.006$ & $+n, 01$ & -- & 0.11 & -0.24 & $=0.2 .7$ \\
\hline+5 weeks at $360^{\circ} \mathrm{C}, \mathrm{FC}$ & +0.002 & +0.006 & +0.01 & -0.16 & -0.24 & -0.29 & -- \\
\hline+1 week at $400^{\circ} \mathrm{C}, \mathrm{FC}$ & -- & -- & -- & -0.16 & -- & -0.24 & -0.31 \\
\hline+3 weeks at $400^{\circ} \mathrm{C}, \mathrm{FC}$ & -- & -- & -- & -0.13 & -- & -0.24 & -0.32 \\
\hline t5 weelss at $100^{\circ} \mathrm{C}, \mathrm{FC}$ & -- & -- & -- & -0.14 & -- & -0.24 & -0.33 \\
\hline As-fabricated & -0.02 & -0.07 & -0.07 & -0.15 & -0.17 & -0.28 & -0.43 \\
\hline
\end{tabular}

* Air cooled

* Furnace cooled

tFailed by cracking within 9 days of test.

$$
3
$$


A graphic presentation of the effect of test temperature on the corrosion properties is included in Fig. 33. When the logarithm of the corrosion rate is plotted against the reciprocal of absolute temperature (Fig. 34), the straight line relationship predicted by the Arrhenius equation is obeyed by the 50 and $60 \mathrm{w} / \mathrm{o}$ alloys but not by the 10 to $35 \mathrm{w} / \mathrm{o}$ alloys.

\section{DISCUSSION OF CORROSION BEHAVIOR}

The corrosion behavior of the zirconium-uranium alloys has been thoroughly discussed and shown to be directly related to the phases present in the alloys (Refs 1, 3, 4, and 5). It will be discussed briefly here for purposes of review. The phase diagram as reported by Saller and Rough is shown in Fig. 35, and typical microstructures are shown in Figs. 36, 37, and 38.

Zirconium +10 to $35 \mathrm{w} / \mathrm{o}$ Uranium Alloys

Quenching from the high temperature $\left(850\right.$ to $\left.1000^{\circ} \mathrm{C}\right)$ range results in a mixture of transformed beta zirconium and epsilon. As the uranium content increases, precipitation of the transformed beta phase is decreased and formation of the epsilon phase is accelerated. Thus, with increasing uranium content, increasing amounts of the epsilon phase are formed. Furthermore, as epsilon corrodes more rapidly than transformed beta zirconium, the corrosion resistance of the alloys should decrease with increasing uranium content.

The equilibrium structure, epsilon plus alpha zirconium, is obtained when the alloys are slowly cooled from all temperatures. However, the amount of the epsilon phase formed also increases with increasing uranium content; thus, the corrosion rates increase with increasing alloy uranium content. Differences between the quenched and slow-cooled specimens are attributed to the greater amounts of the epsilon phase which precipitate during slow cooling. Slight variations in the corrosion properties exhibited by individual alloys are to be expected because of the formation of alpha as well as differences in the distribution of the epsilon phase in the alpha zirconium matrix.

The alpha precipitate coalesces and coarsens when the alloys are held isothermally for extended periods of time in the temperature range around $600^{\circ} \mathrm{C}$, which results in a continuous heavy network of epsilon. It has been postulated that the deleterious effects caused by aging at $575^{\circ} \mathrm{C}$ are caused by this heavy network of epsilon (Ref 1). Increasing corrosion rates should be obtained with increasing uranium content or increasing time at $575^{\circ} \mathrm{C}$ as the network becomes more continuous.

Isothermal-treatments at $360^{\circ} \mathrm{C}$ appear to have little or no effect upon the martensitic alpha (transformed beta) phase formed during direct quenching from the high temperature region; thus, the treatment produces no effect upon corrosion of individual alloys.

Zirconium $+50 \mathrm{w} / 0$ Uranium Alloys

Zirconium alloys containing approximately 45 to $55 \mathrm{w} / 0$ uranium are essentially single phase epsilon, since transformation starts very rapidly, even at temperatures as low as $260^{\circ} \mathrm{C}(\mathrm{Ref} 5)$. Thus, the corrosion behavior is insensitive to heat treatment.

Zirconium $+60 \mathrm{w} / 0$ Uranium Alloys

Zirconium alloys containing more than $55 \mathrm{w} / \mathrm{o}$ uranium exhibit either the body-centered cubic gamma phase after quenching from high temperature, or epsilon plus alpha uranium phase after slow cooling from the high temperature or heating in the low temperature (less than $600^{\circ} \mathrm{C}$ ) range.

The high corrosion rates, mechanisms, and associated disintegration (discontinuous fàilure) of the gamma phase alloys have been attributed to the oxidation of a metastable hydride of uranium which is precipitated during corrosion (Ref 7 ).

The corrosion of the aged and slow-cooled specimens is believed to be controlled by variations in the distribution of the alpha uranium nelwurk in the epsilon matrix resulting from time and temperature treatments. 


\section{REFERENCES}

1. W. E. Berry and R. S. Peoples, "The Corrosion Behavior of Zirconium Uranium Alloys in High Temperature Water," Corrosion, Vol 14 (1958), p 414 t.

2. S. Kass and K. M. Guldman, "Corrosion Behavior of Uranium-Zirconium Alloys in High Temperature Water and Steam," Bettis Atomic Power Division Technical Paper WAPD-T-416, (April 1958).

3. A. A. Bauer, S. Kass, and K. M. Goldman, "Physical Metallurgy and Properties of ZirconiumUranium Alloys," Sec. U. N. Inter. Conf. on Peaceful Uses of Atomic Energy, A/CONF. 15/P/1785, (Jun 1958).

4. D. L. Douglass, L. L. Marsh, and G. K. Manning, "Transformation Kinetics of ZirconiumUranium Alloys, " Trans. ASM, Vol 50, (1958), p 305.

5. J. J. Kearns, "Transformation Kinetics of Uranium-Zirconium Alloys Containing 50 and 60 Wt Pct Uranium," Bettis Atomic Power Division Technical Paper WAPD-T-417, (Nov. 21, 1956).

6. H. A. Saller and F. A. Rough, "Compilation of U. S. and U. K. Uranium and Thorium Constitutional Diagrams," BMI-1000, (June 1, 1955).

7. M. W. Burkart and B. Lustman, "Corrosion Mechanism of Uranium-Base Alloys in High Temperature Water," Trans. AIME, Vol 212, (1958), p 26. 


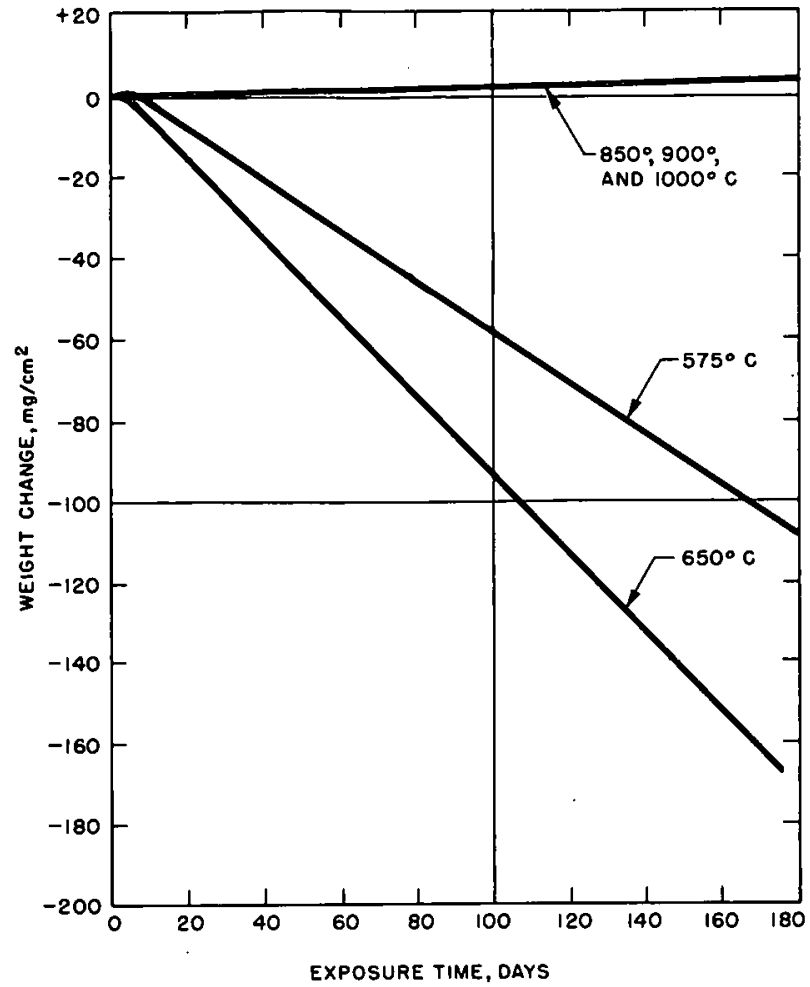

Fig. I Effect of Temperature on the $360^{\circ} \mathrm{C}$ Water Corrosion Behavior of Zirconium $+10 \mathrm{w} / 0$ Uranium; Samples Quenched from Temperature

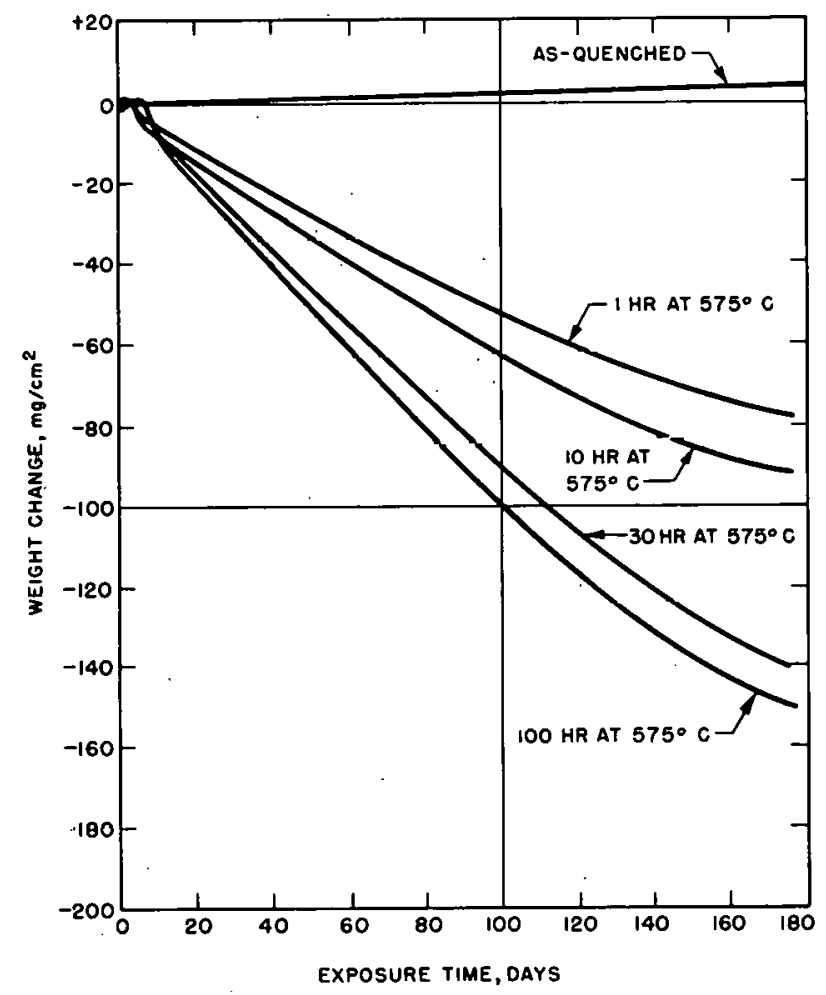

Fig. $3360^{\circ} \mathrm{C}$ Water Corrosion of Zirconium + $10 \mathrm{w} / \mathrm{o}$ Uranium Quenched from $850^{\circ} \mathrm{C}$. Subsequently Aged at $575^{\circ} \mathrm{C}$, and Slowly cooled

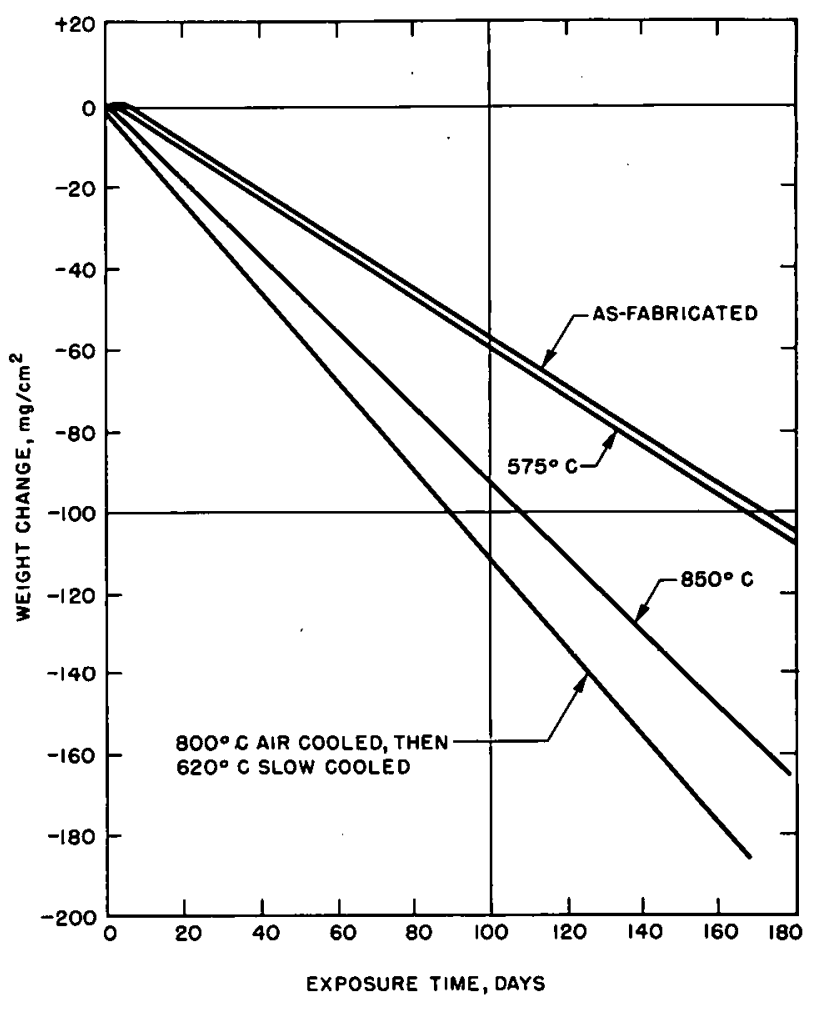

Fig. 2 Effect of Temperature on the $360^{\circ} \mathrm{C}$ Water Corrosion Behavior of Zirconium $+10 \mathrm{w} / 0$ Uranium: Samples Slowly Cooled from Temperature

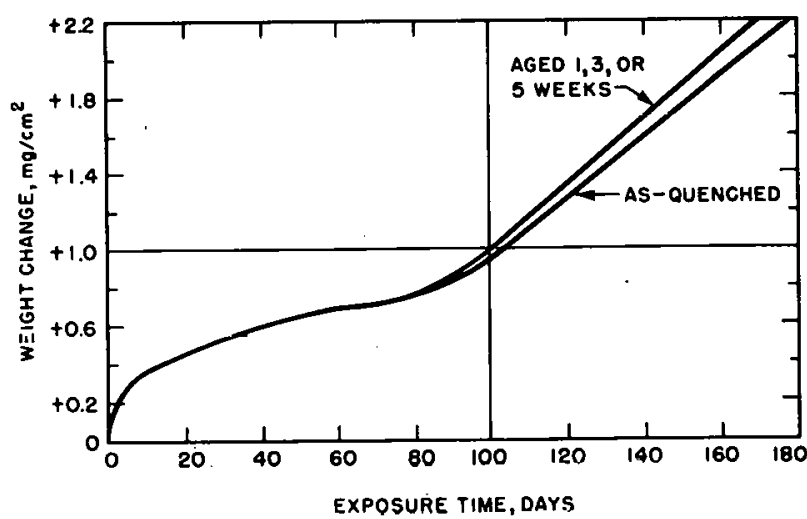

Fig. $4360^{\circ} \mathrm{C}$ Hater Corrosion of Zirconium + $10 \mathrm{w} / \mathrm{o}$ Uranium Quenched fium $850^{\circ} \mathrm{C}$. Subsequently Aged at $360^{\circ} \mathrm{C}$, and Slowly Cooled 


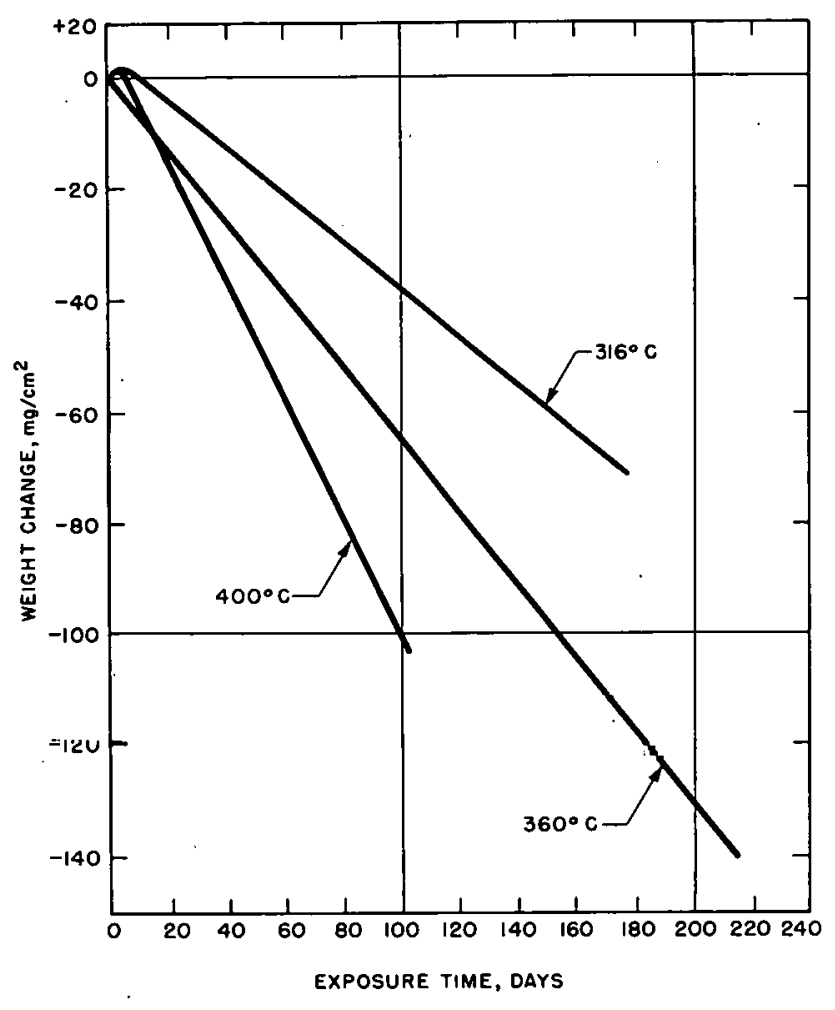

Fig. 5 Effect of Temperature on the Corrosion of Zirconium + $10 \mathrm{w} / 0$ Uranium; Samples Slowly Cooled from $575^{\circ} \mathrm{C}$

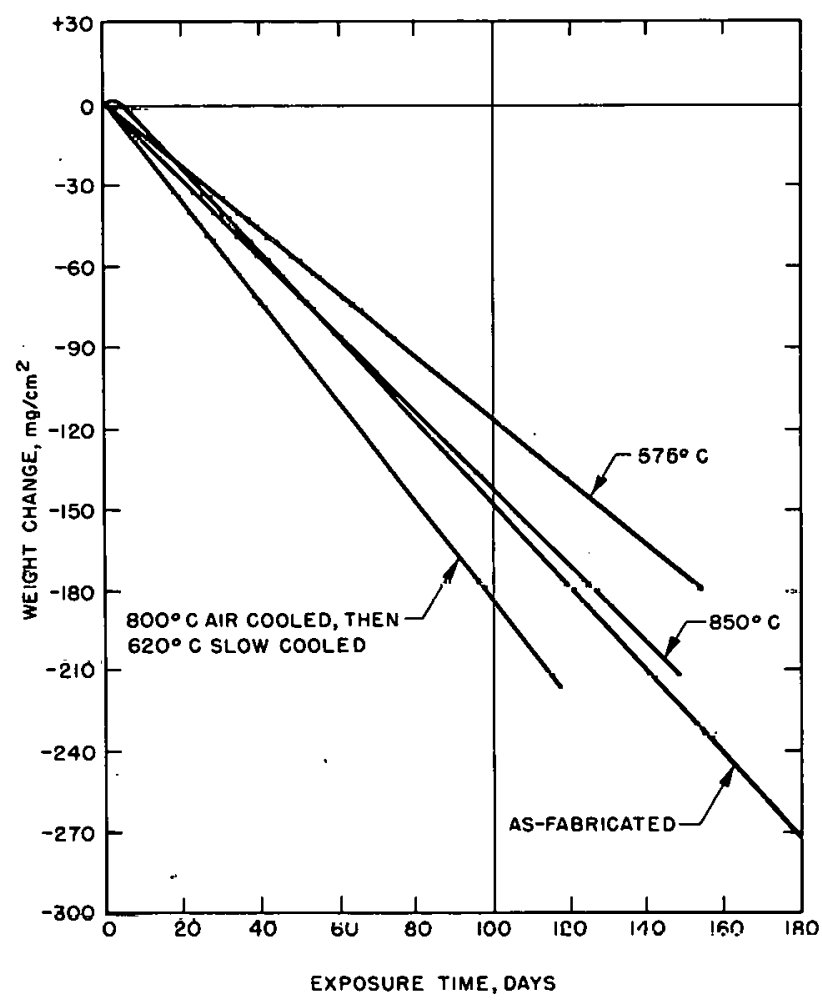

Fig. 7 Effect of Temperature on the $360^{\circ} \mathrm{C} \mathrm{Water}$ Corrosion Behavior of Zirconium $+15 \mathrm{w} / \mathrm{o}$ Uranium: Samples Slowly Cooled from Temperature

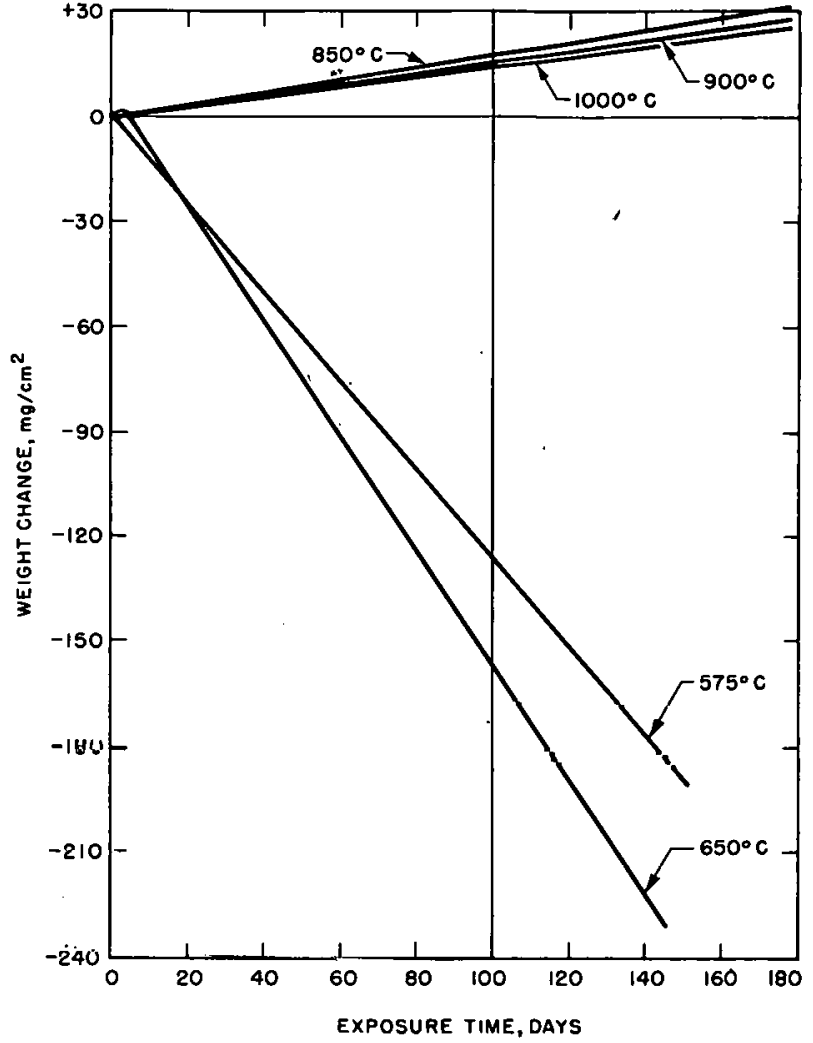

Fig. 6 Effect of Temperature on the $360^{\circ} \mathrm{C}$ Water Corrosion Behavior of Zirconium + 15 w/o Uranium; Samples Quenched from Témperature

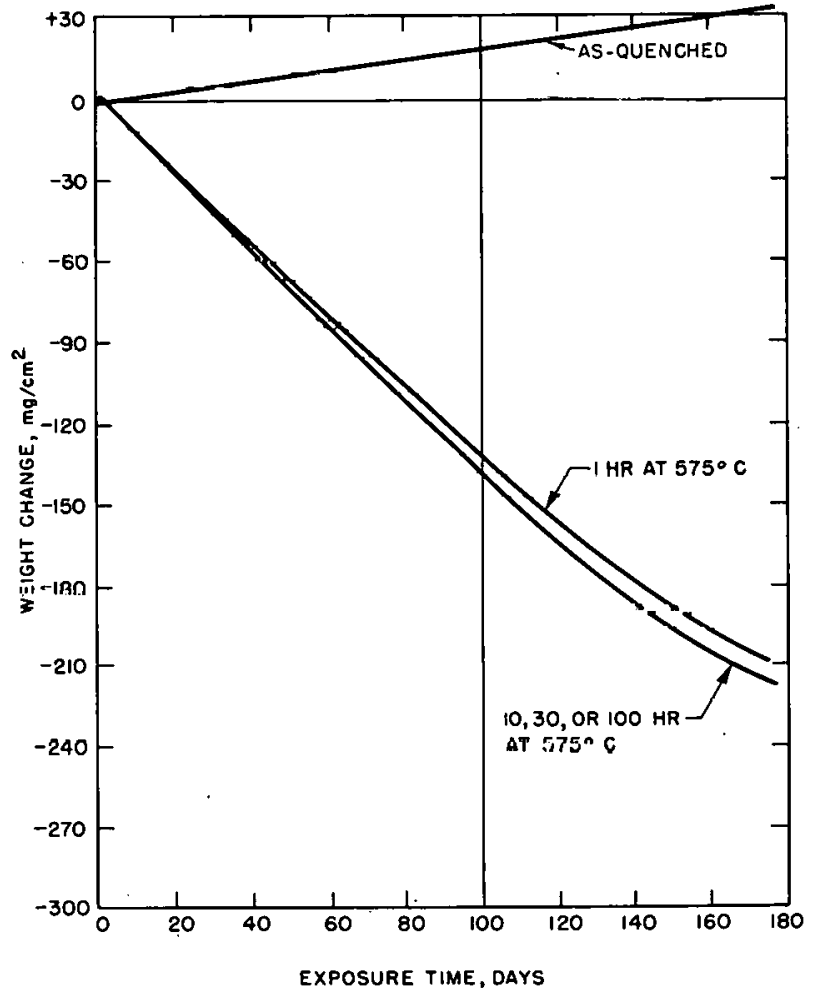

Fig. $8360^{\circ} \mathrm{C}$ Water Corrosion of Zirconium + $15 \mathrm{w} / \mathrm{o}$ Uranium: Quenched from $850^{\circ} \mathrm{C}$, Subsequently Aged at $575^{\circ} \mathrm{C}$, and Slowly Cooled 


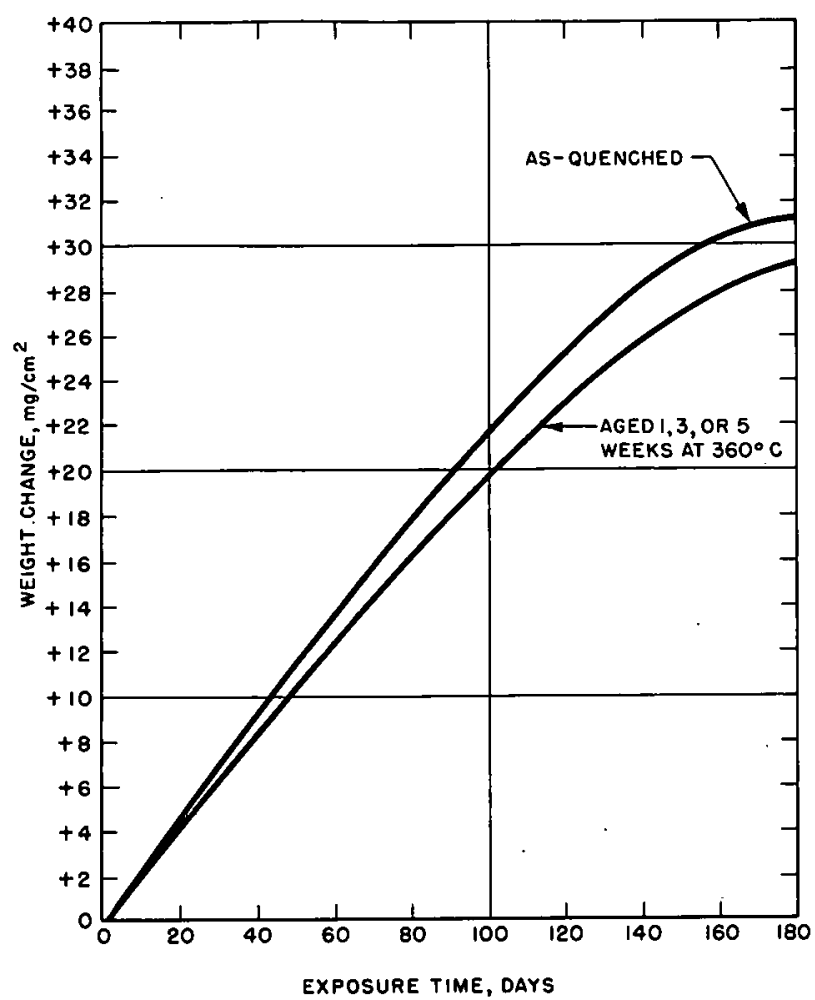

Fig. $9360^{\circ} \mathrm{C}$ Water Corrosion Behavior of Zirconium + 15 w/o Uranium: Quenched from $850^{\circ} \mathrm{C}$, Subsequently Aged at $360^{\circ} \mathrm{C}$ and Slowly Cooled

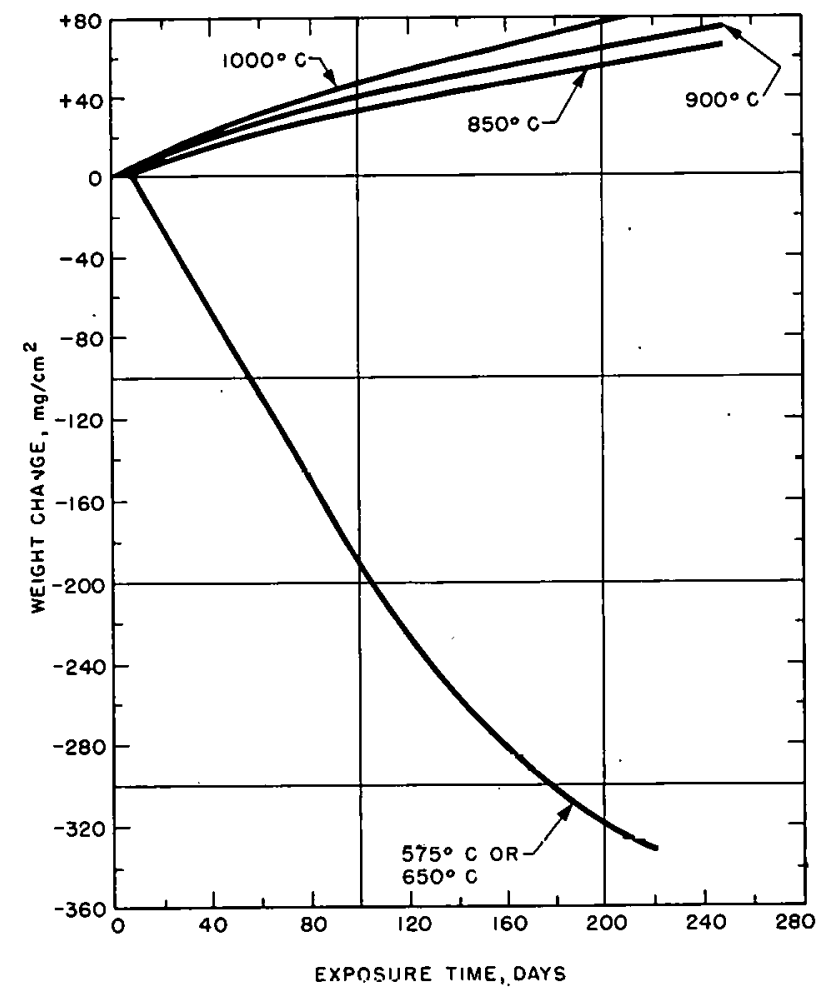

Fig. 11 Effect of Temperature on the $360^{\circ} \mathrm{C}$ Water Corrosion Behavior of Zirconium + $20 \mathrm{w} / \mathrm{o}$ Uranium; Samples Quenched from Temperature

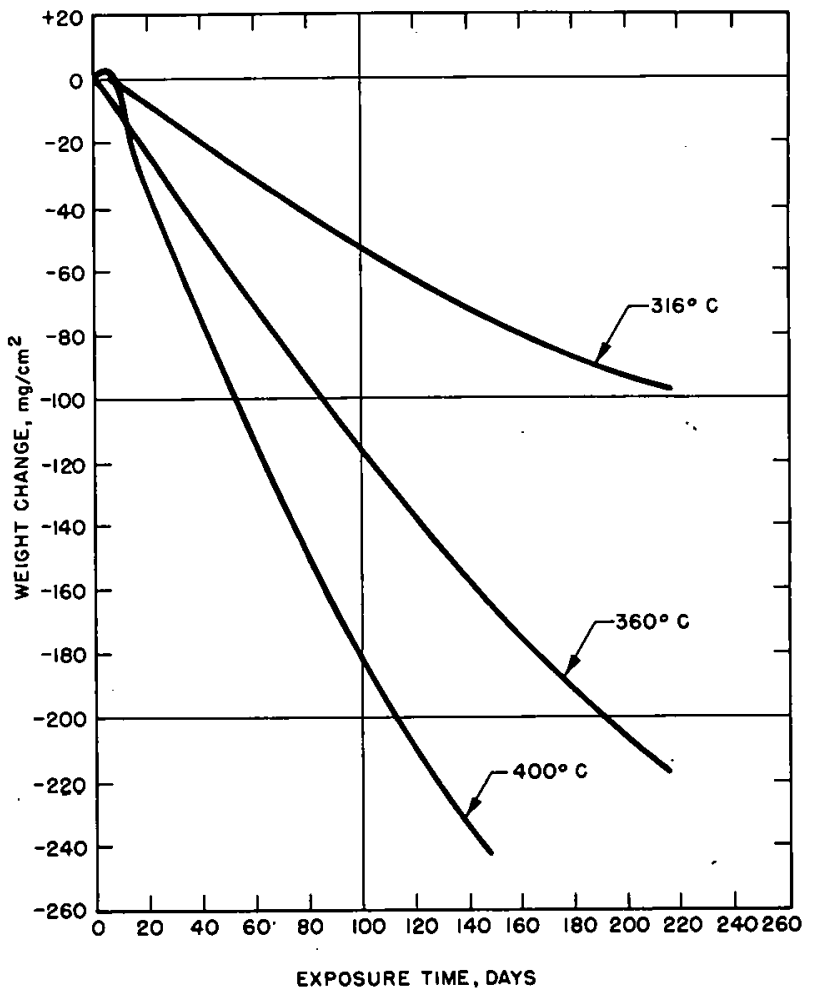

Fig. 10 Effect of Temperature on the Corrosion of Zirconium $+15 \cdot w / 0$ Uranium; Samples Slowly Cooled from $575^{\circ} \mathrm{C}$

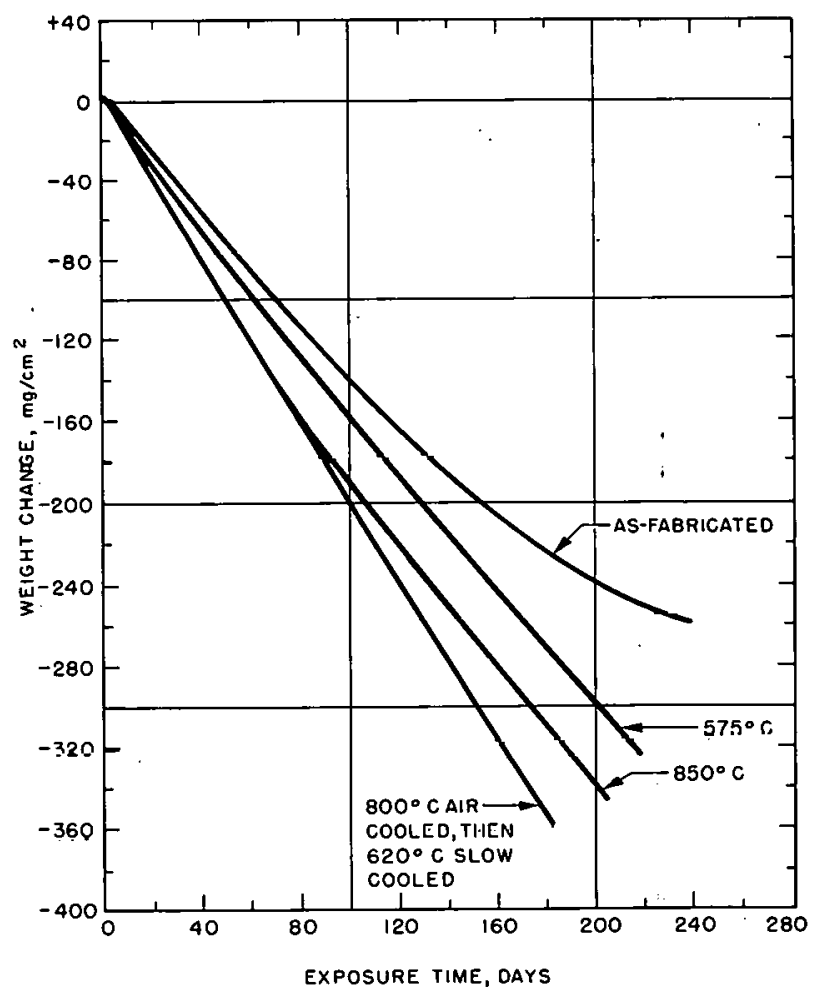

Fig. 12 Effect of Temperature on the $360^{\circ} \mathrm{C}$ Water Corrosion Behavior of Zirconium + $20 \mathrm{w} / \mathrm{o}$ Uranium; Samples Slowly. Cuoled from Temperature 


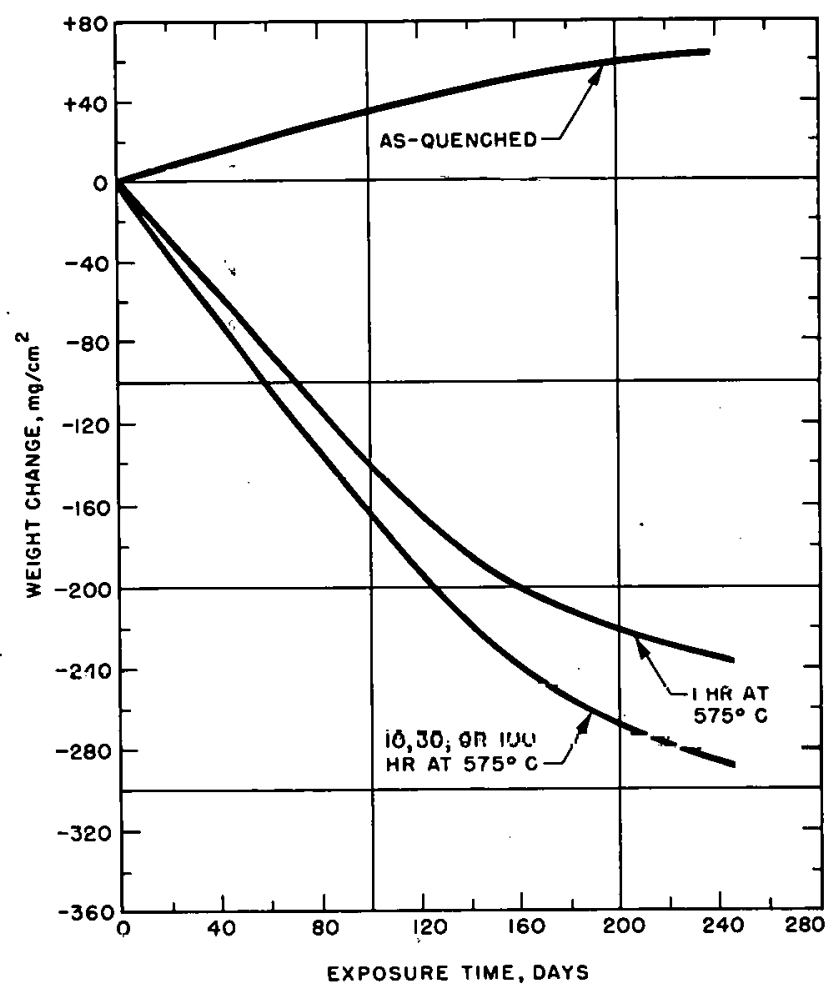

Fig. $13360^{\circ} \mathrm{C}$ Water Corrosion of Zirconium + 20 w/o Uranium; Quenched from $850^{\circ} \mathrm{C}$, Subsequently Aged at $575^{\circ} \mathrm{C}$, and Slowly Coioled

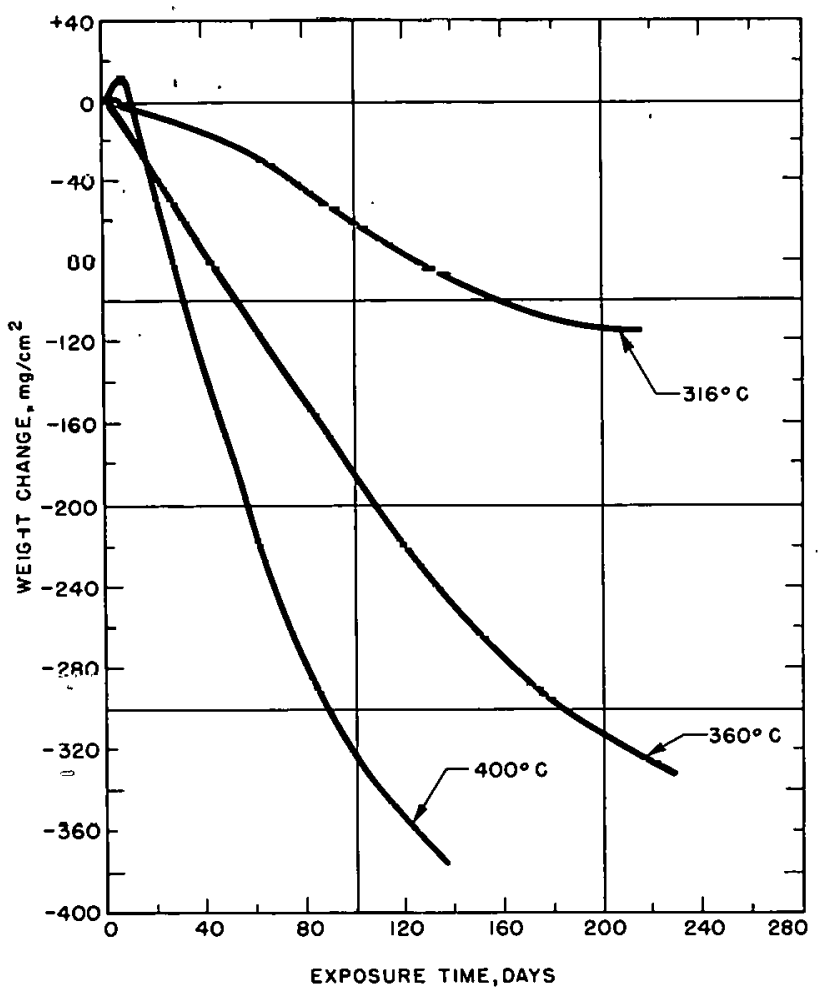

Fig. 15 Effect of Temperature on the Corrosion of Zirconium $+20 \mathrm{w} / \mathrm{o}$ Uranium; Samples Slowly Cooled from $575^{\circ} \mathrm{C}$

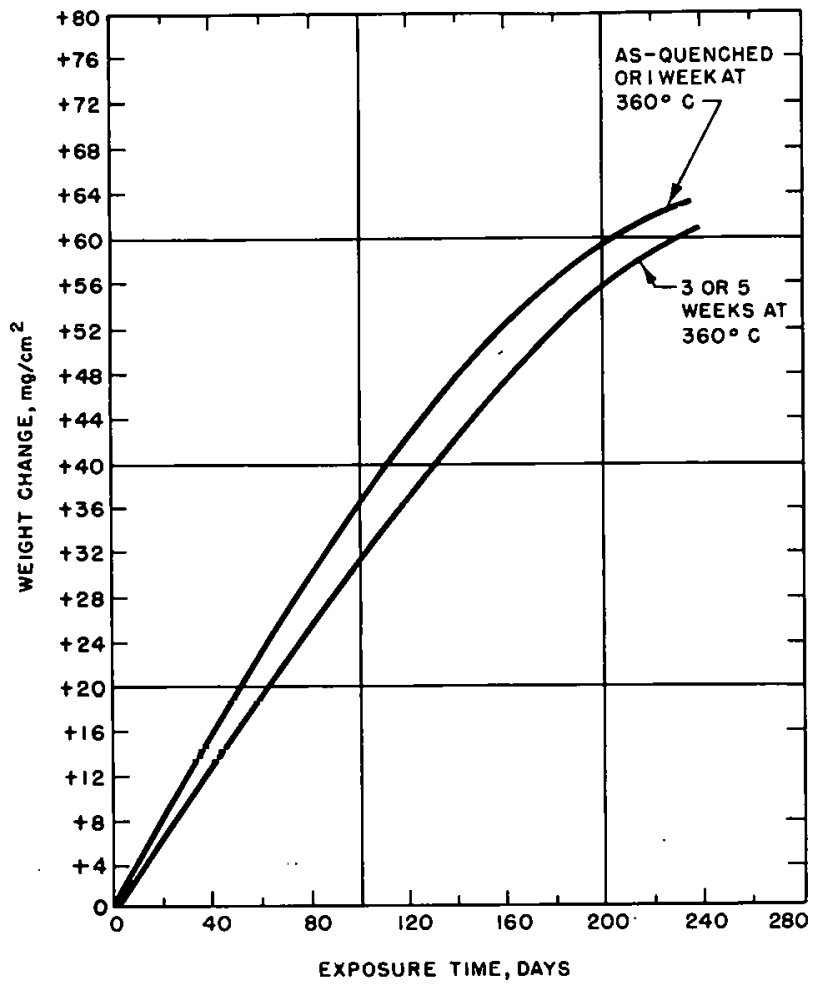

Fig. $14360^{\circ} \mathrm{C}$ Water Corrosion of Zirconium + 20 w/o Uranium; Quenched from $850^{\circ} \mathrm{C}$. Subsequently Aged at $360^{\circ} \mathrm{C}$, and Slowly cooled

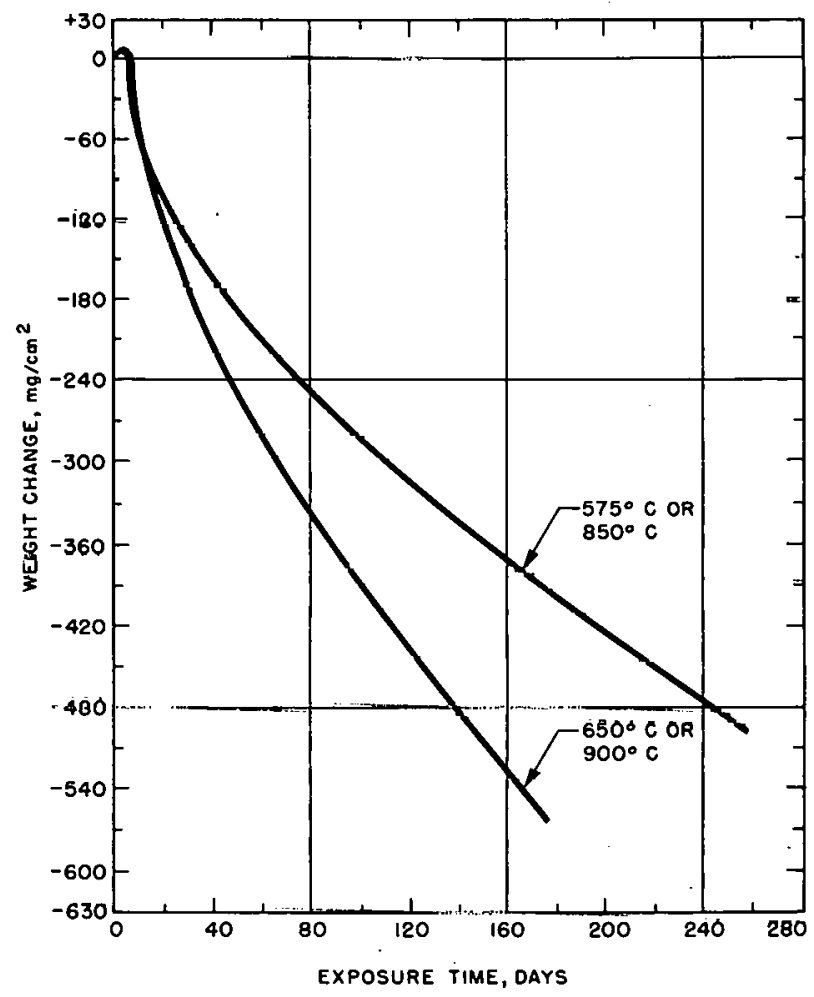

Fig. 16 Effect of Temperature on the $360^{\circ} \mathrm{C}$ Water Corrosion Behavior of Zirconium + 35 w/o Uranium; Samples Quenched from Temperature 


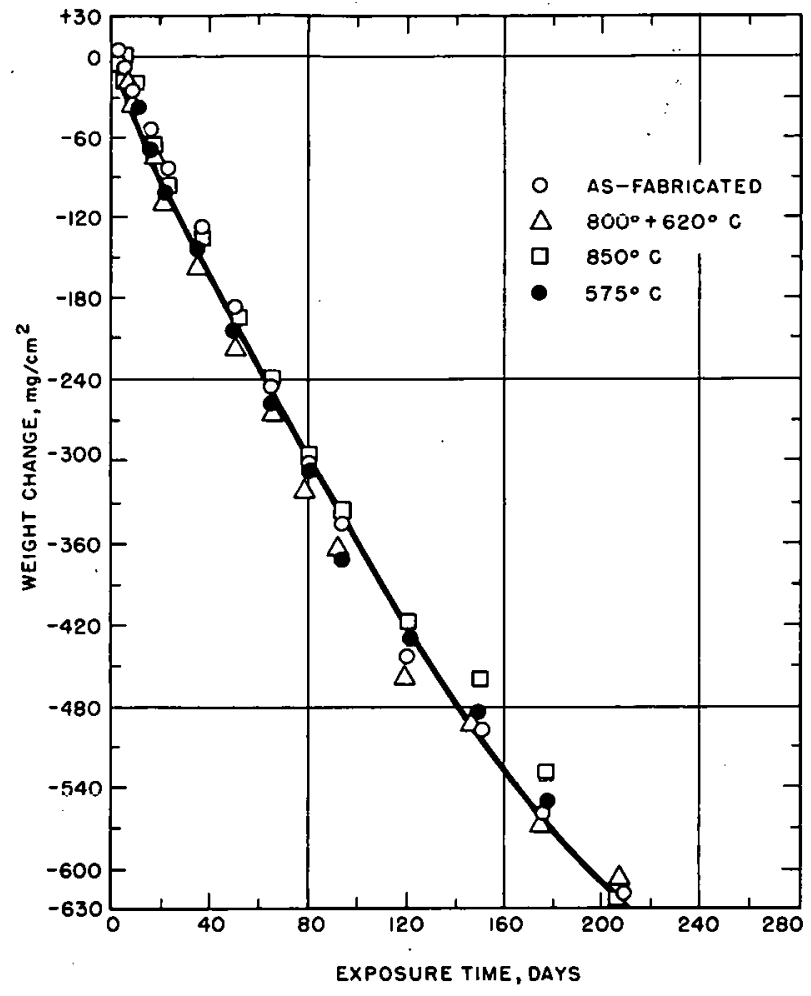

Fig. 17 Effect of Temperature on the $360^{\circ} \mathrm{C}$ Water Corrosion Behavior of Zirconium + $35 \mathrm{w} / \mathrm{O}$ Uranium; Samples Slowly Cooled from Temperature

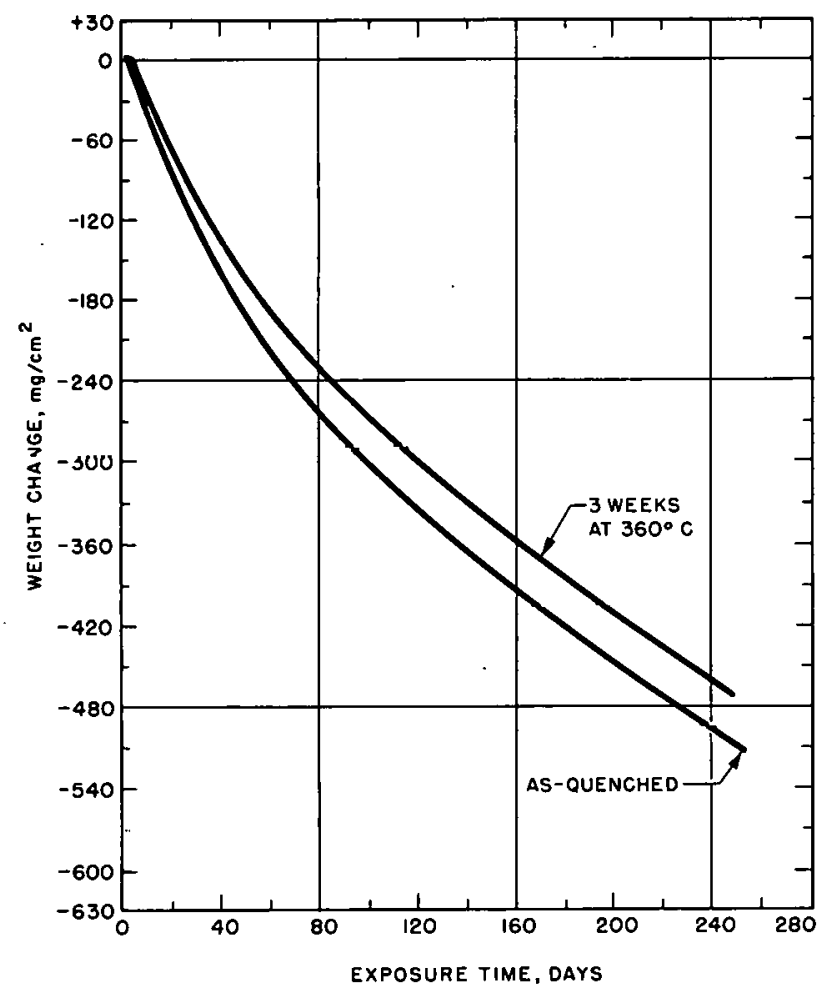

Fig. $19360^{\circ} \mathrm{C}$ Water Corrosion of Zirconium + $35 \mathrm{w} / \mathrm{o}$ Uranium: Quenched from $850^{\circ} \mathrm{C}$. Subsequently Annealed at $360^{\circ} \mathrm{C}$, and Slowly Cooled

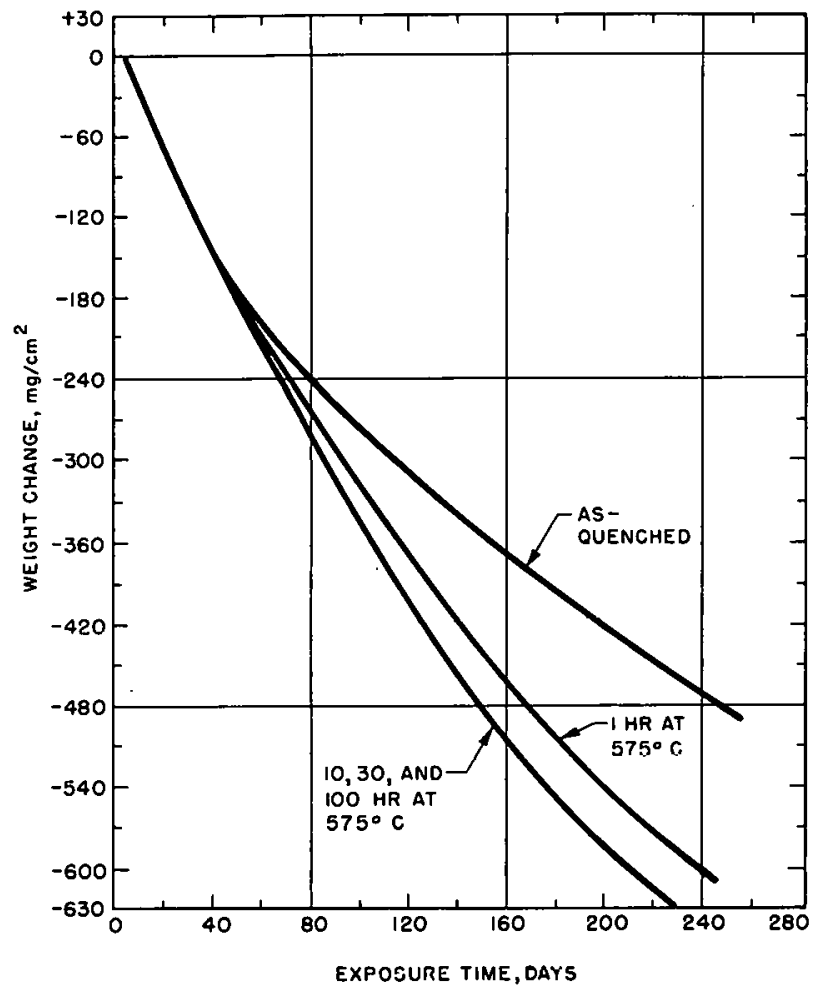

Fig. $18360^{\circ} \mathrm{C}$ Water Corrosion of Zirconium + $35 \mathrm{w} / \mathrm{o}$ Uranium: Quenched from $850^{\circ} \mathrm{C}$, Subsequently Aged at $575^{\circ} \mathrm{C}$, and Slowly Cooled

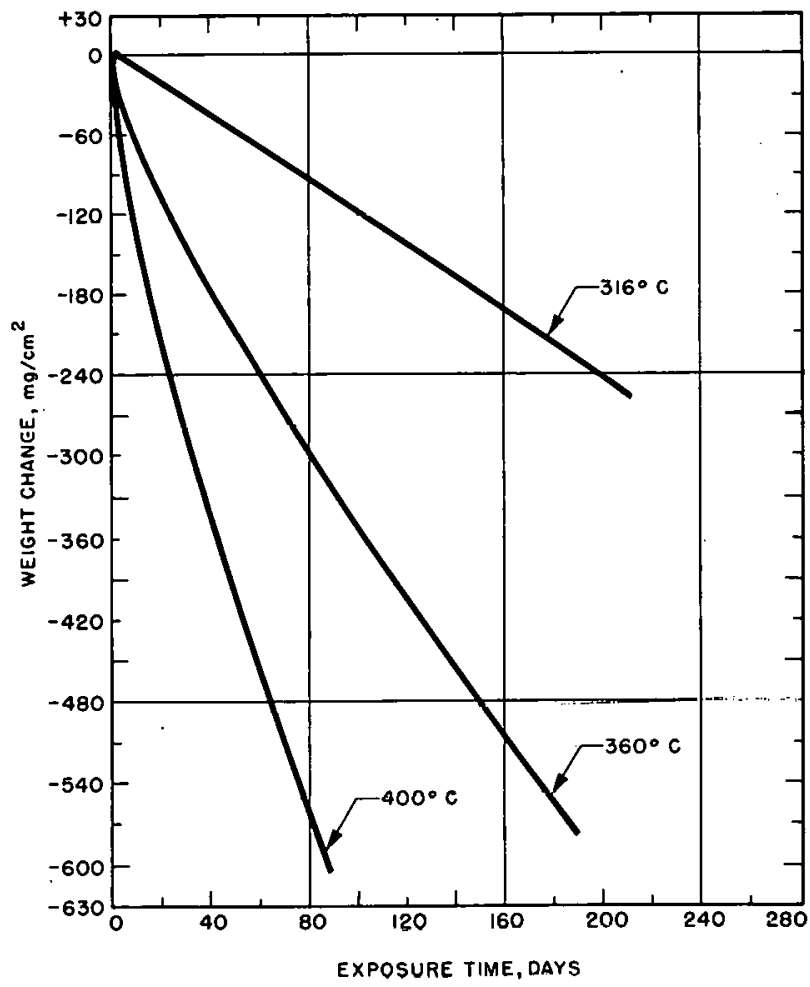

Fig. 20 Effect of Temperature on the Corrosion of Zirconium +35 wio Urarlium; Samples slowly Cooled from $575^{\circ} \mathrm{C}$ 


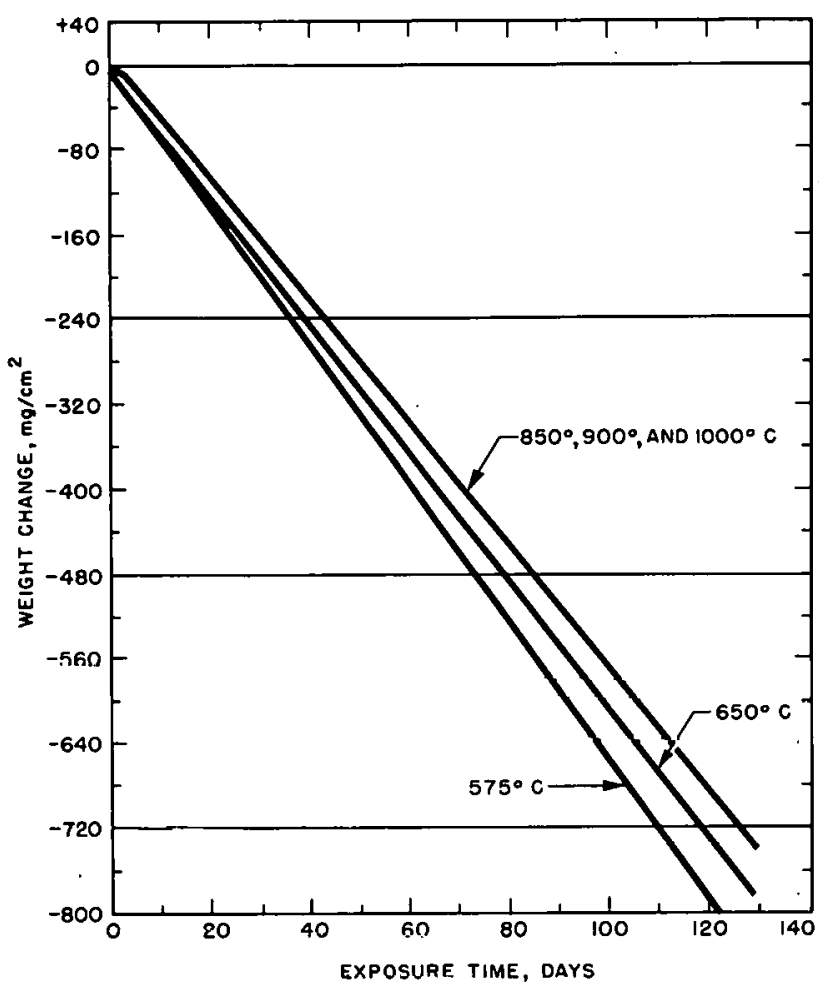

Fig. 21 Effect of Temperature on the $360^{\circ} \mathrm{C}$ Water Corrosion Behavior of Zirconium + 50 w/o Uranium: Samples Quenched from Temperature

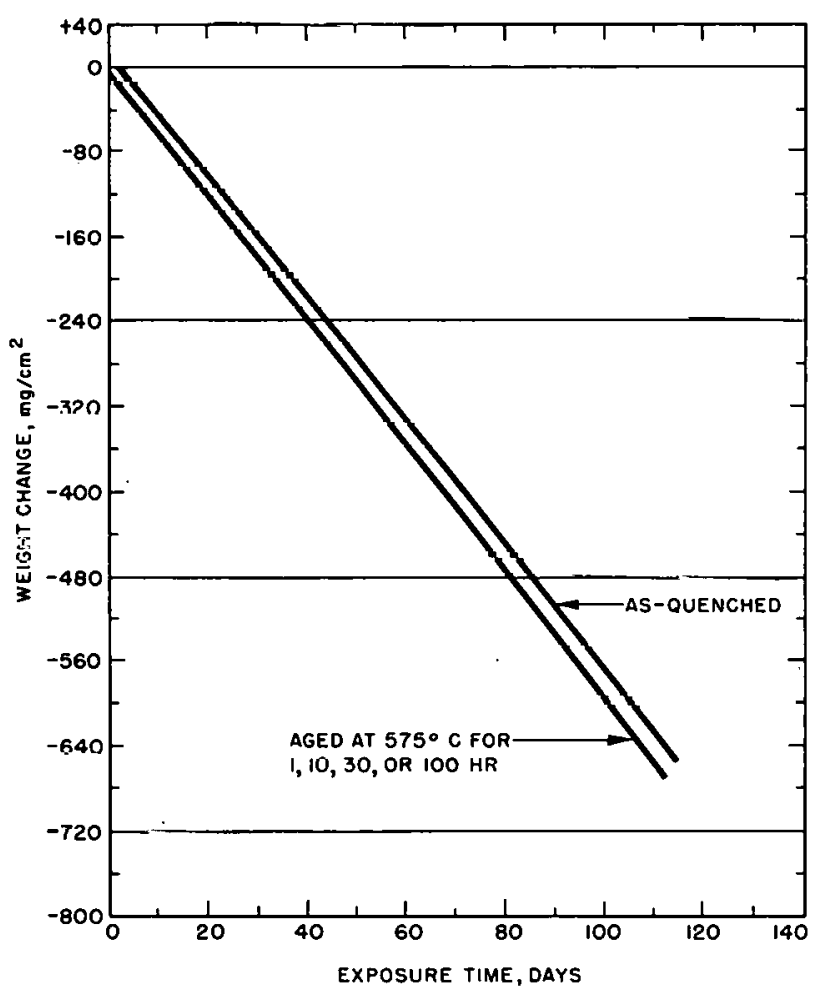

Fig. $23360^{\circ} \mathrm{C}$ Water Corrosion of Zirconium + $50 \mathrm{w} / 0$ Uranium; Quenched from $850^{\circ} \mathrm{C}$. Subsequently Annealed at $575^{\circ} \mathrm{C}$, and Slowly Cooled

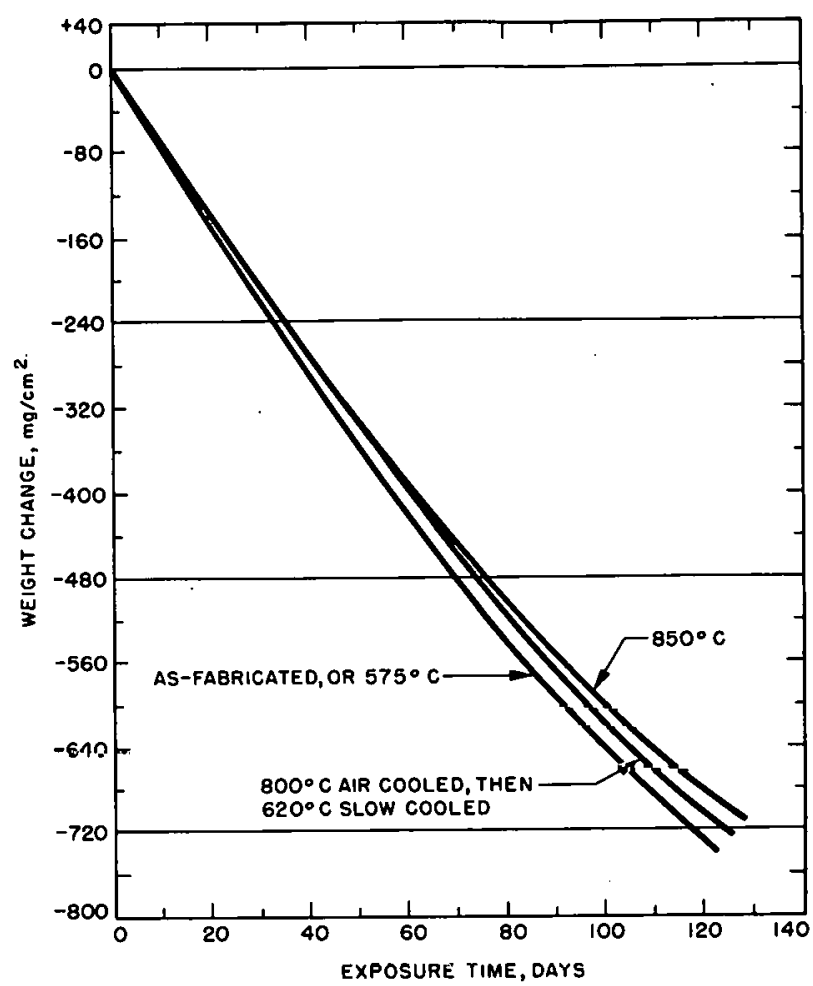

Fig. 22 Effect of Temperature on the $360^{\circ} \mathrm{C}$ Water Corrosion Behavior of Zirconium + 50 w/o Uranium: Samples Slowly. Cooled from Temperature

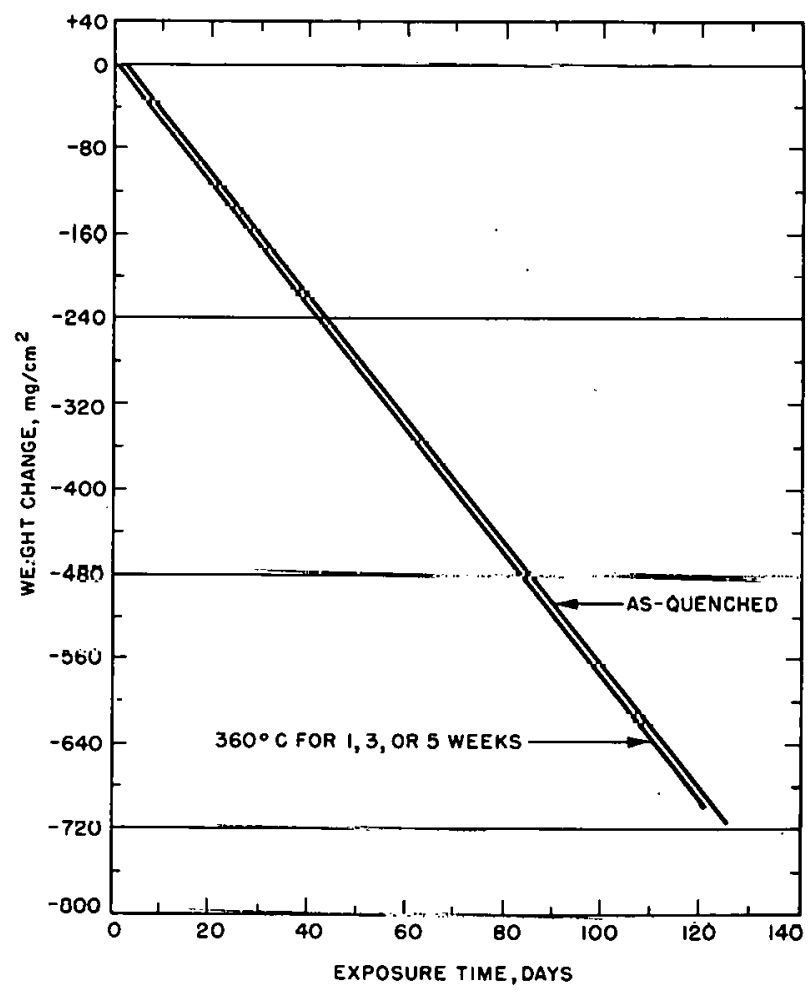

Fig. $24360^{\circ} \mathrm{C}$ Water Corrosion of Lirconium + $50 \mathrm{w} / \mathrm{o}$ Uranium; Quenched from $850^{\circ} \mathrm{C}$, Subsequently Annealed at $360^{\circ} \mathrm{C}$, and Slowly Cooled 


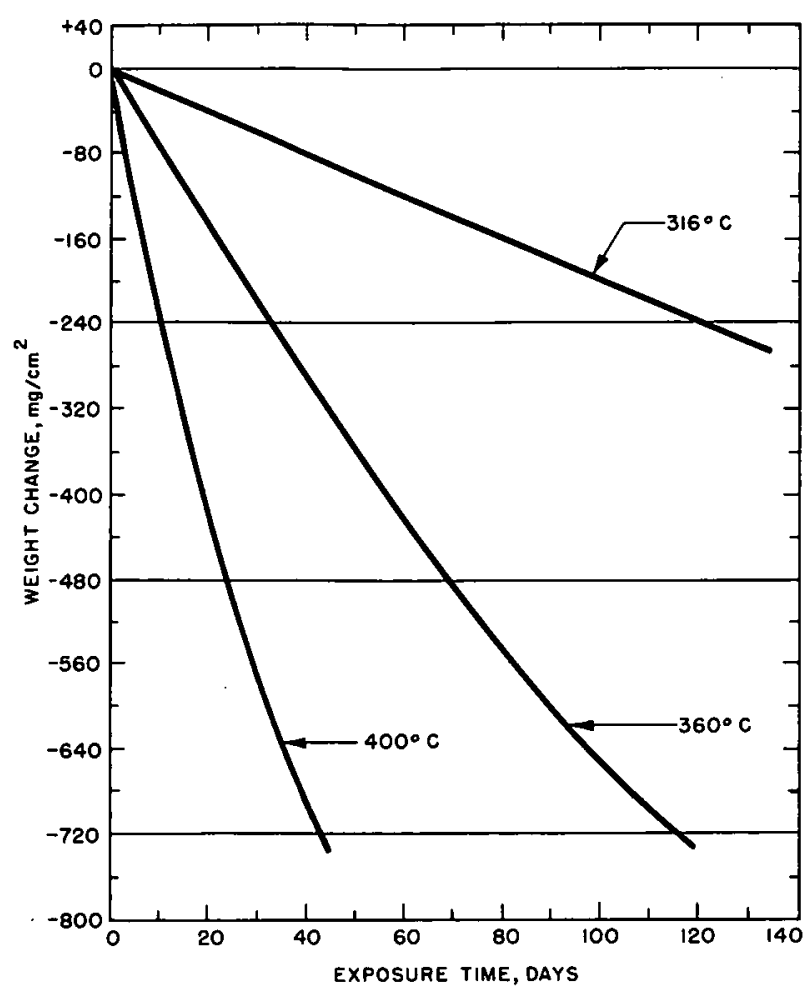

Fig. 25 Effect of Temperature on the Corrosion of Zirconium + 50 w/o Uranium; Samples slowly Cooled from $575^{\circ} \mathrm{C}$

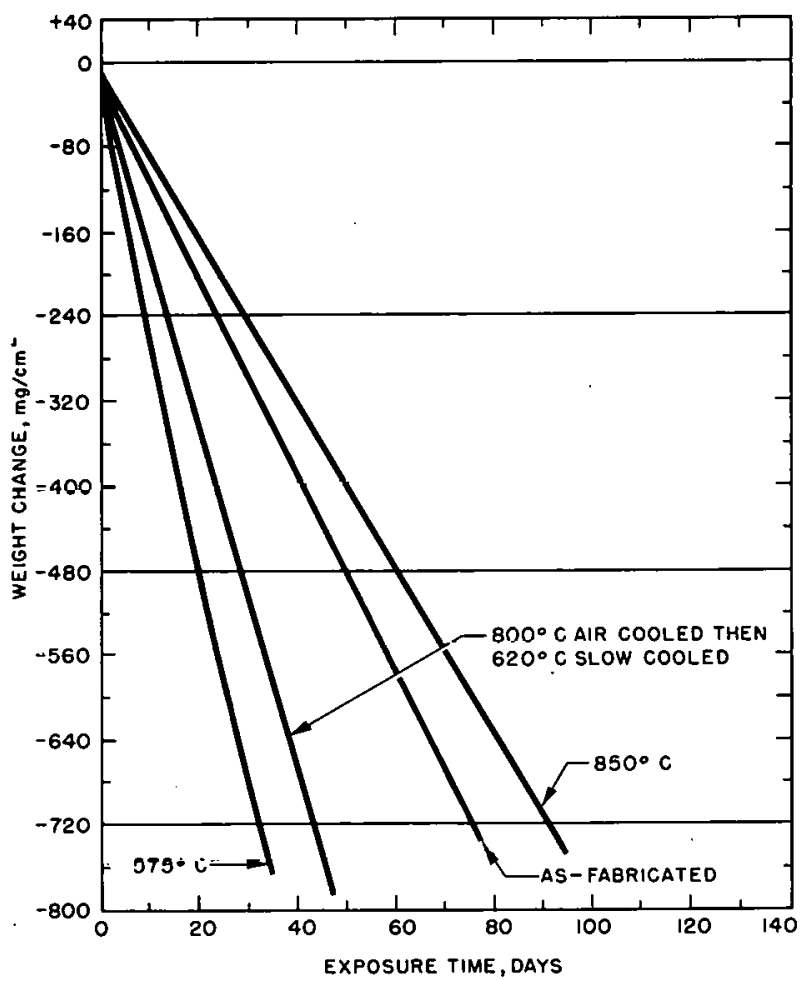

Fig. 27 Effect of Temperature on the $360^{\circ} \mathrm{C}$ Water Corrosion Behavior of Zirconium + 60 w/o Uranium; Samples Slowly Cooled from Temperature

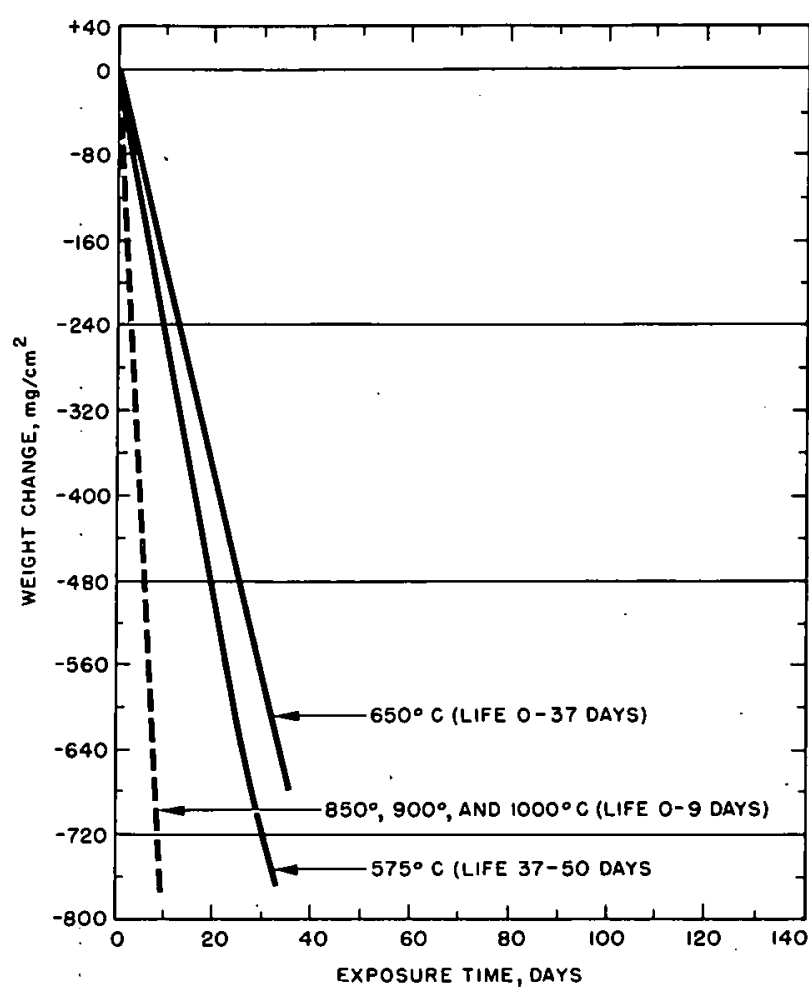

Fig. 26 Effect of Temperature on the $360^{\circ} \mathrm{C}$ Water Corrosion Behavior of Zirconium + 60 w/o Uranium; Samples Quenched from Temperature

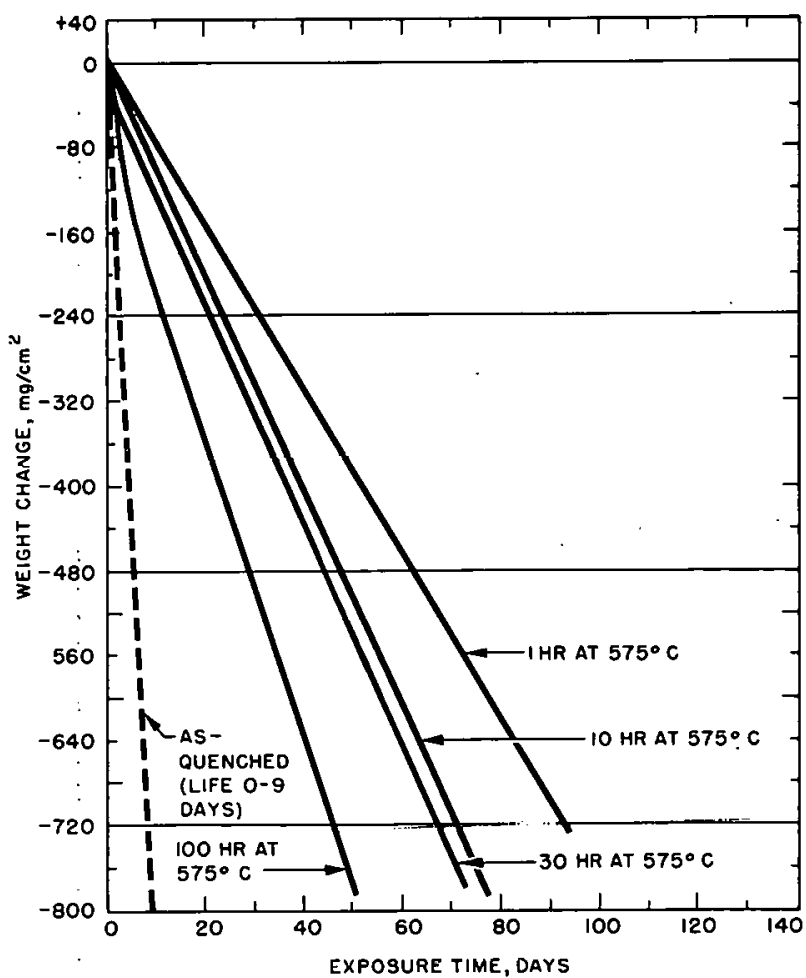

Fig: $28360^{\circ} \mathrm{C}$ Water Corrosion of Zirconium + $60 \mathrm{w} / \mathrm{O}$ Uranium; Quenched from $850^{\circ} \mathrm{C}$. Subsequently Annealed at $.575^{\circ} \mathrm{C}$, and Slowly Cooled 


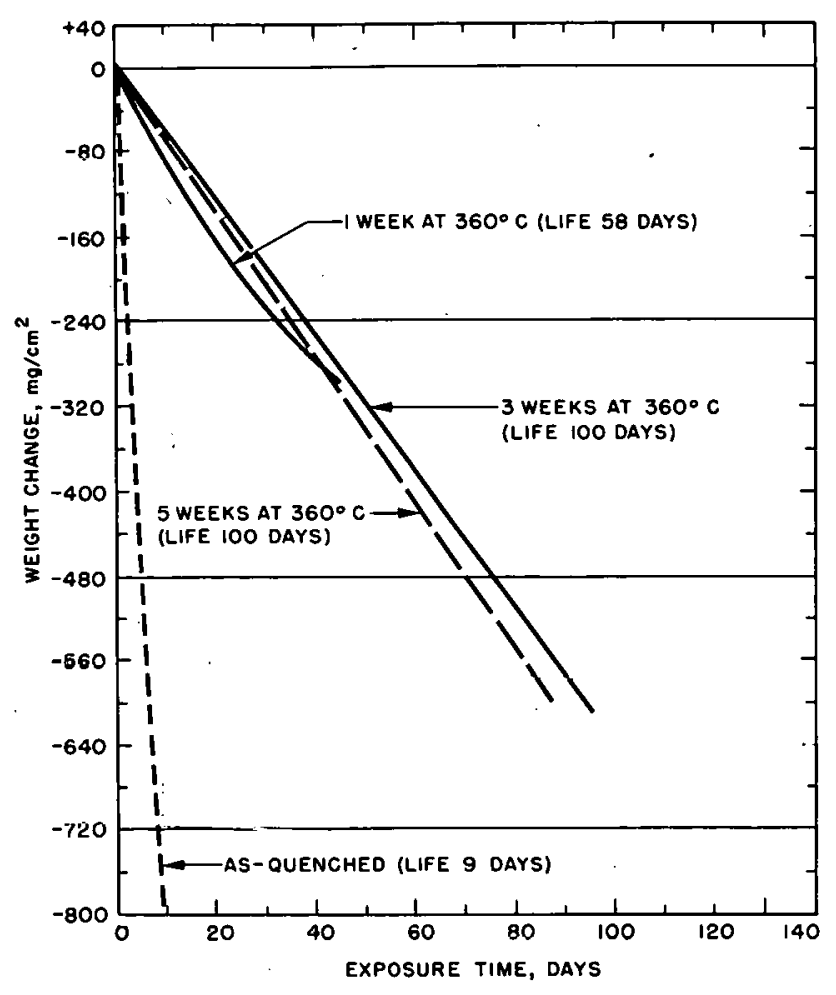

Fig. $29360^{\circ} \mathrm{C}$ Water Corrosion of Zirconium + $60 \mathrm{w} / \mathrm{O}$ Uranium; Quenched from $850^{\circ} \mathrm{C}$. Subsequently Annealed at $360^{\circ} \mathrm{C}$, and Slowly Cooled

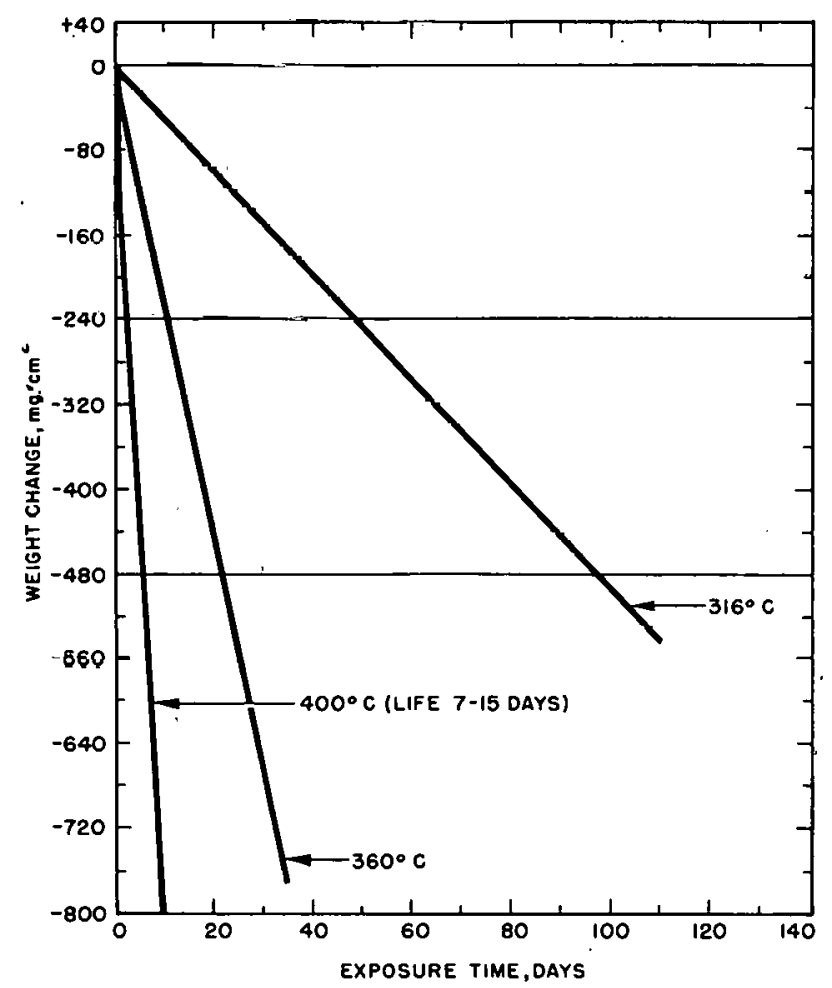

Fig. 31 Effect of Temperature on the Corrosion of Zirconium + 60 w/o Uranium; Samples Slowly Cooled from $575^{\circ} \mathrm{C}$

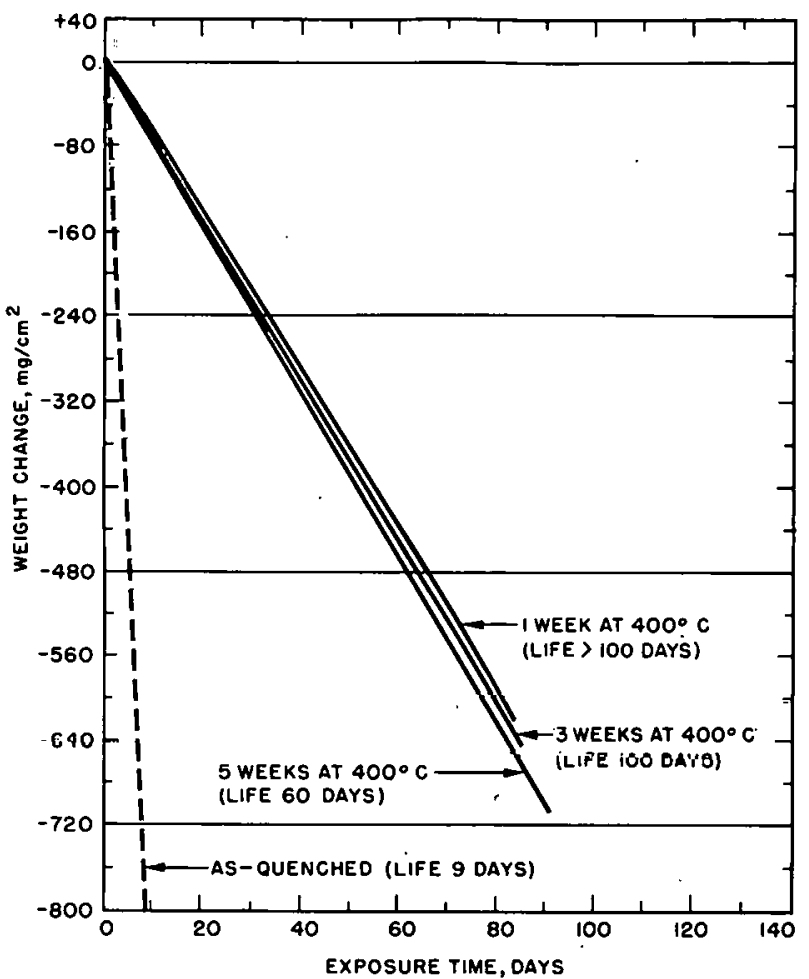

Fig. $30360^{\circ} \mathrm{C}$ Water corroslun of zirionium + $60 \mathrm{w} / 0$ Uranium; Quenched from $850^{\circ} \mathrm{C}$. Subsequently Annealed at $400^{\circ} \mathrm{C}$, and Slowly Cooled.

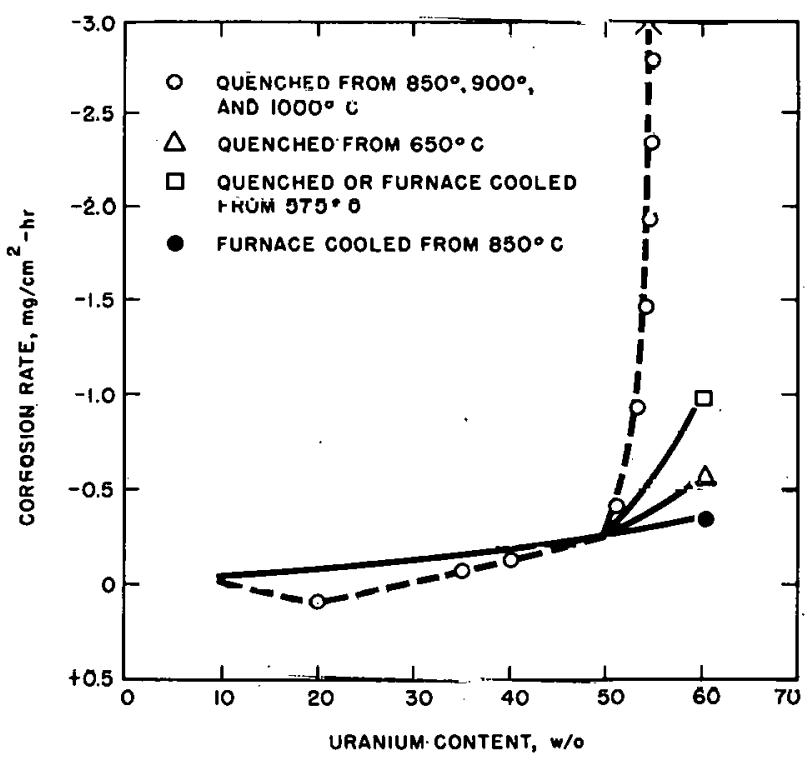

Fig. $32360^{\circ} \mathrm{C}$ Water Corrosion of ZirconiumUranium Alloys 


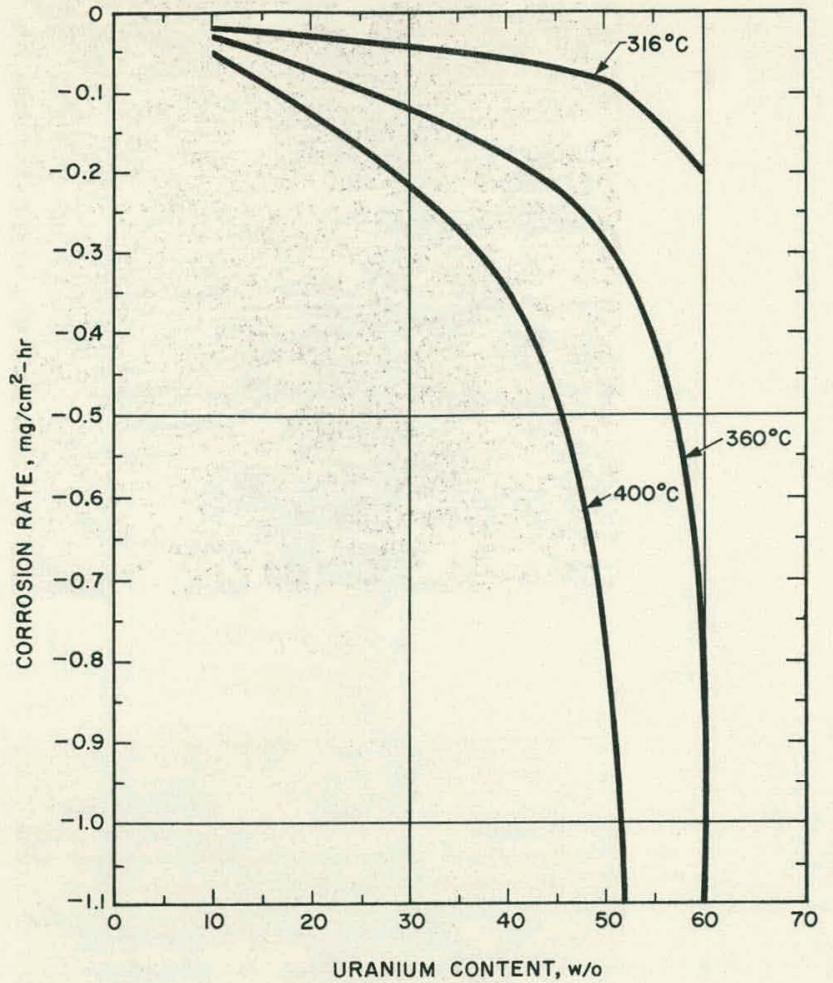

Fig. 33 Effect of Test Temperature on the Corrosion of Zirconium-Uranium Alloys; Samples Slowly Cooled from $575^{\circ} \mathrm{C}$

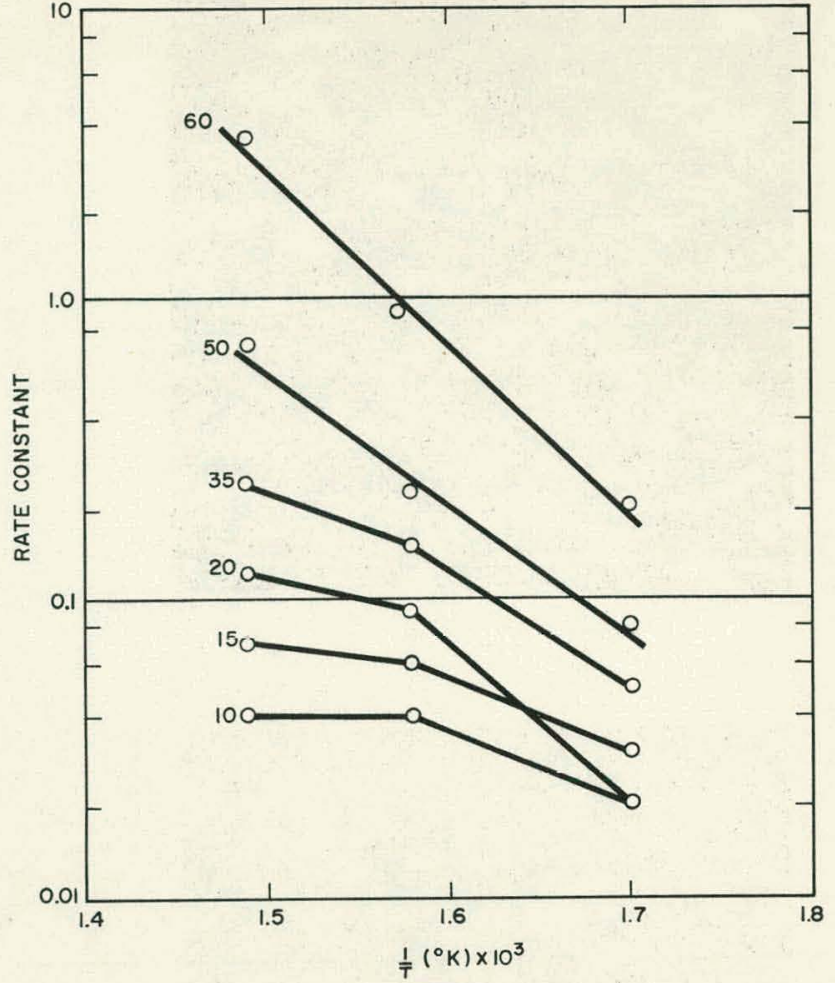

Fig. 34 Effect of Temperature on the Corrosion Rate of Zirconium-Uranium Alloys

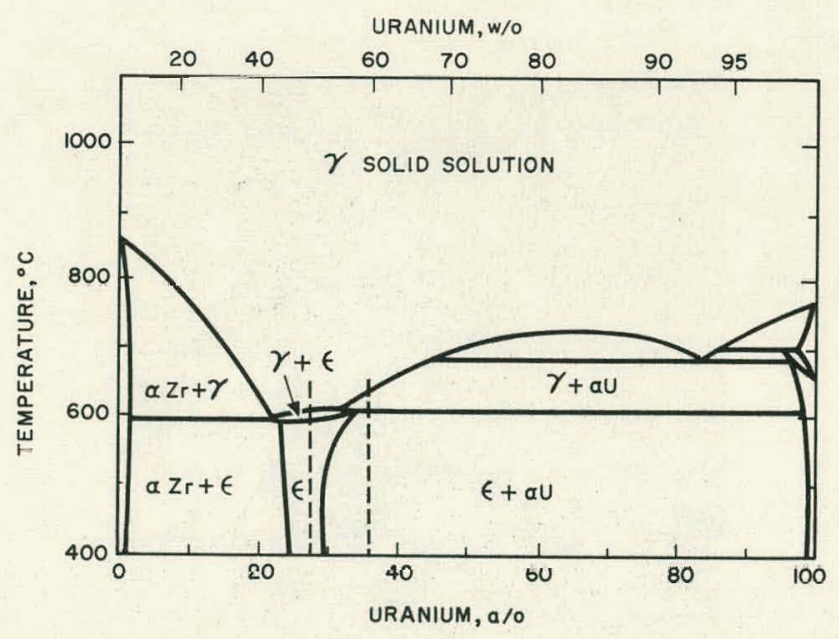

Fig. 35 Phase Diagram of the Zirconium-Uranium System 


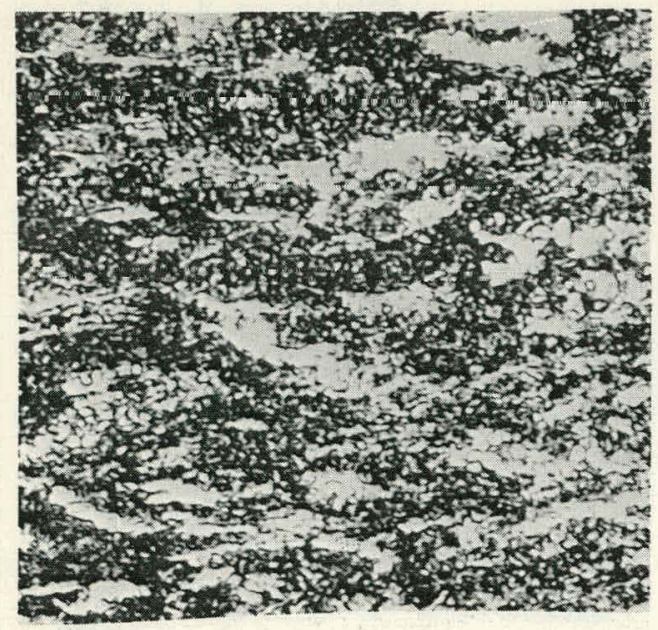

$575^{\circ} \mathrm{C}$

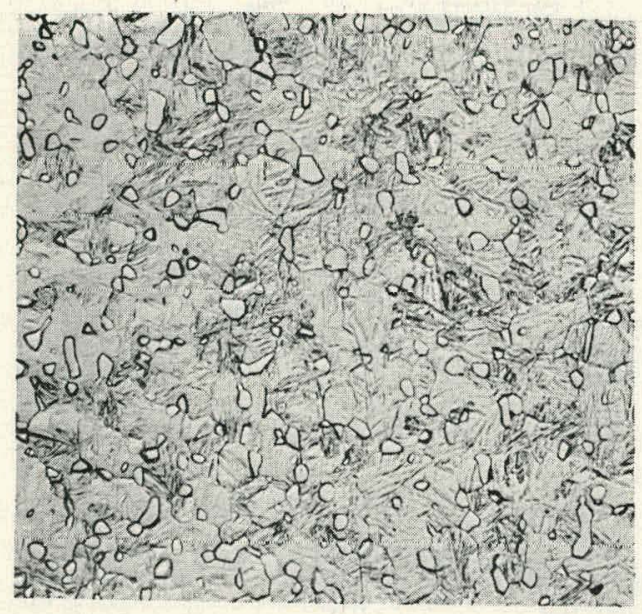

$850^{\circ} \mathrm{C}$

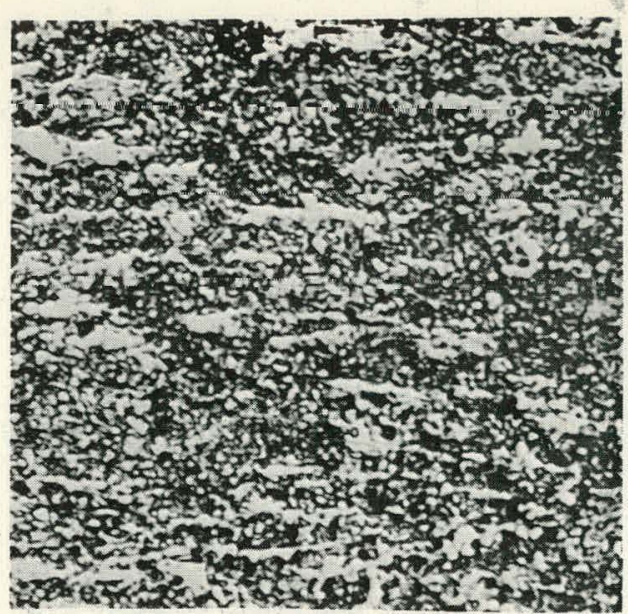

$650^{\circ} \mathrm{C}$

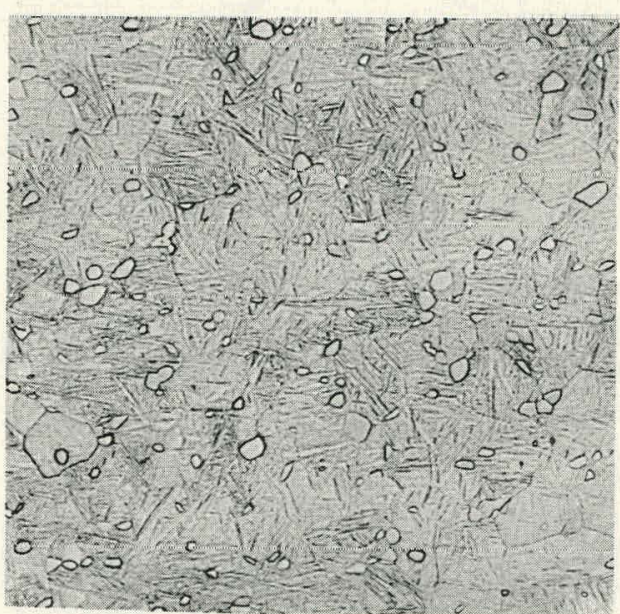

$900^{\circ} \mathrm{C}$

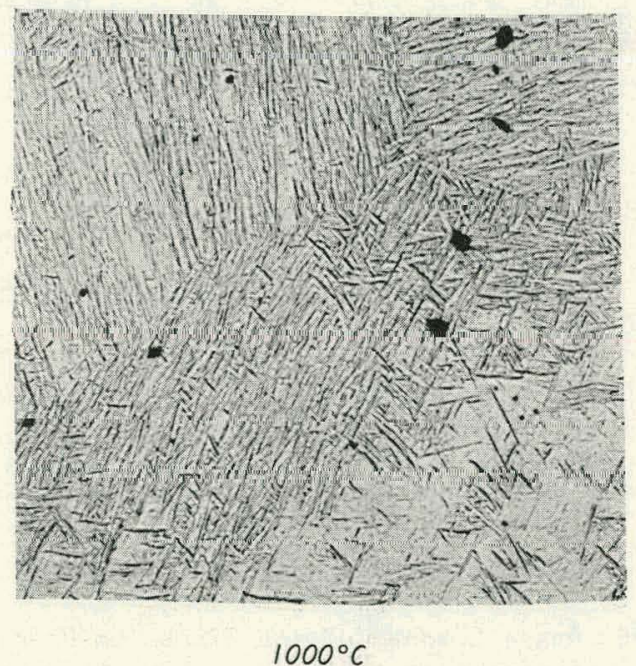

Fig. 36 Typical Microstructures of Quenched Zirconium + 10 w/o Uranium Alloys; All 250x 


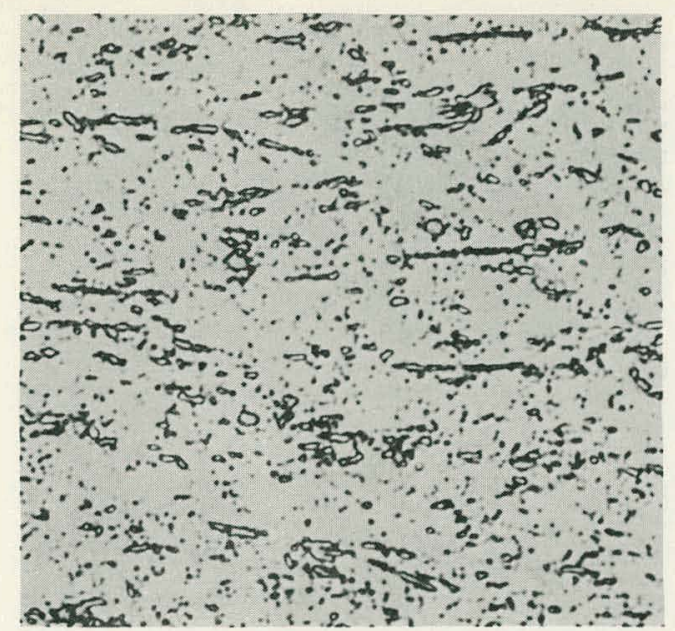

$575^{\circ} \mathrm{C}$

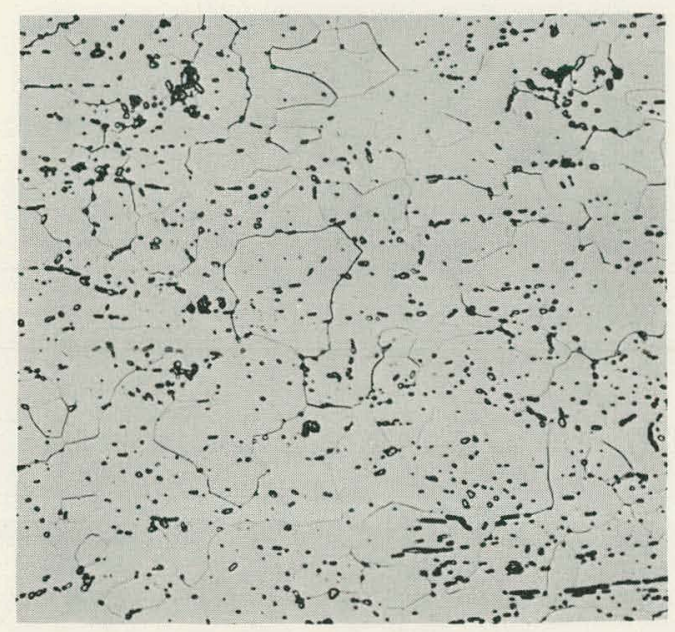

$850^{\circ} \mathrm{C}$

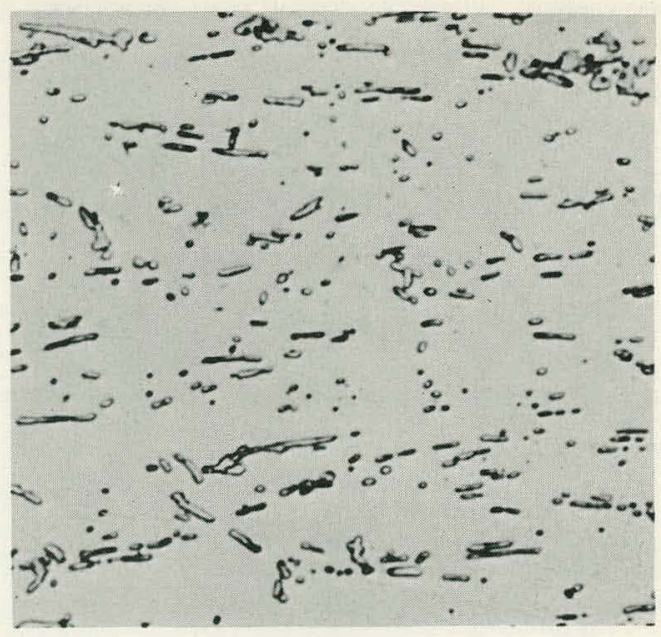

$650^{\circ} \mathrm{C}$

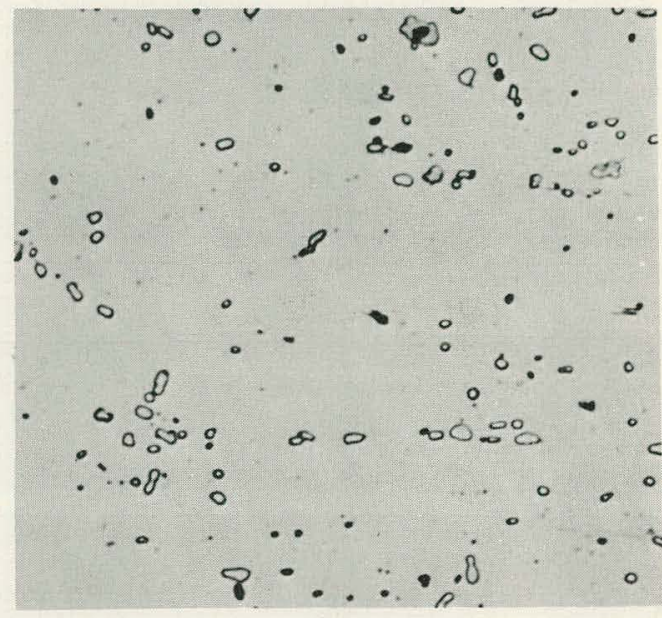

$900^{\circ} \mathrm{C}$

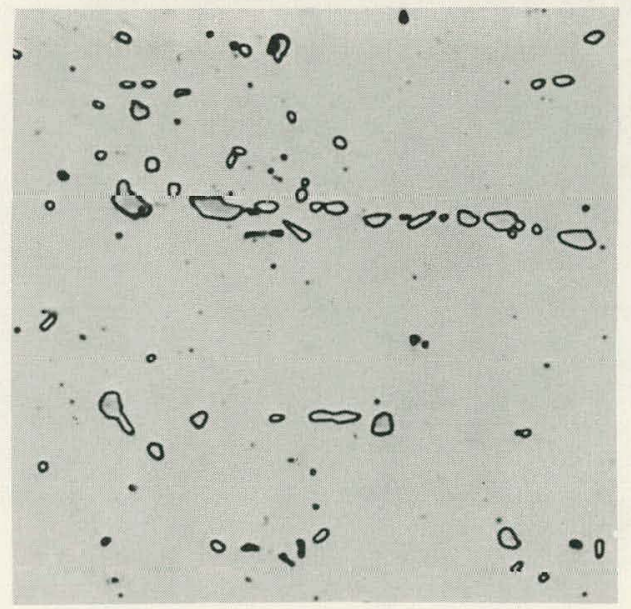

$1000^{\circ} \mathrm{C}$

Fig. 37 Typical Microstructures of Quenched Zirconium + $50 \mathrm{w} / 0$ Uranium Alloys; All 250X 


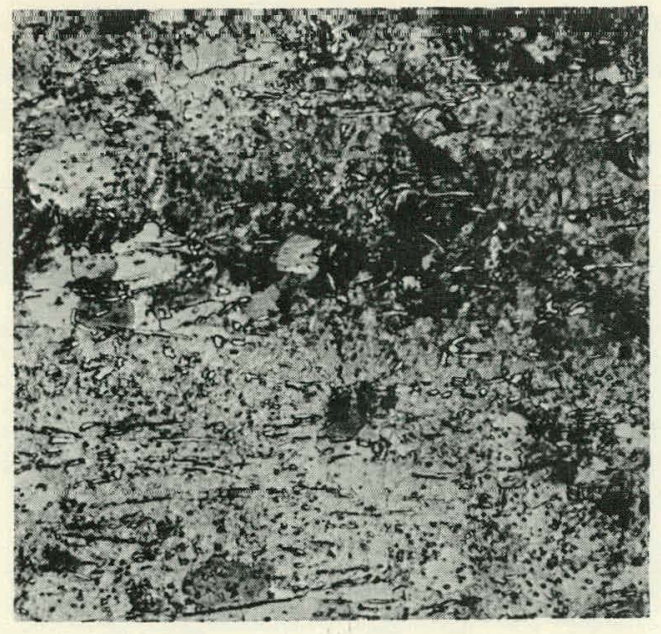

$575^{\circ} \mathrm{C} ; 500 \mathrm{X}$

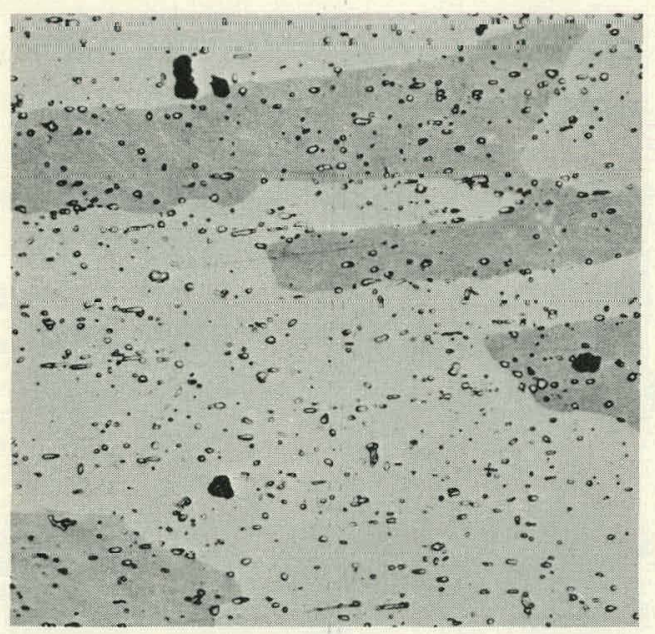

$850^{\circ} \mathrm{C} ; 250 \mathrm{X}$

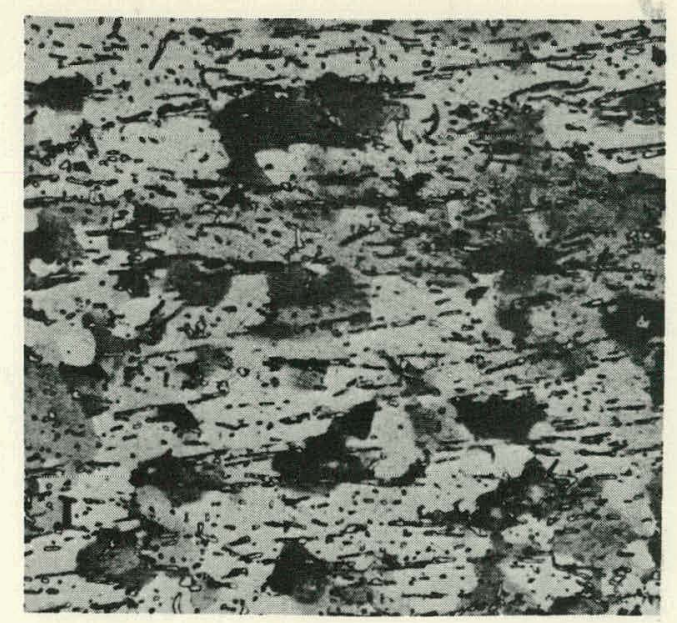

$650^{\circ} \mathrm{C}$; $500 \mathrm{X}$

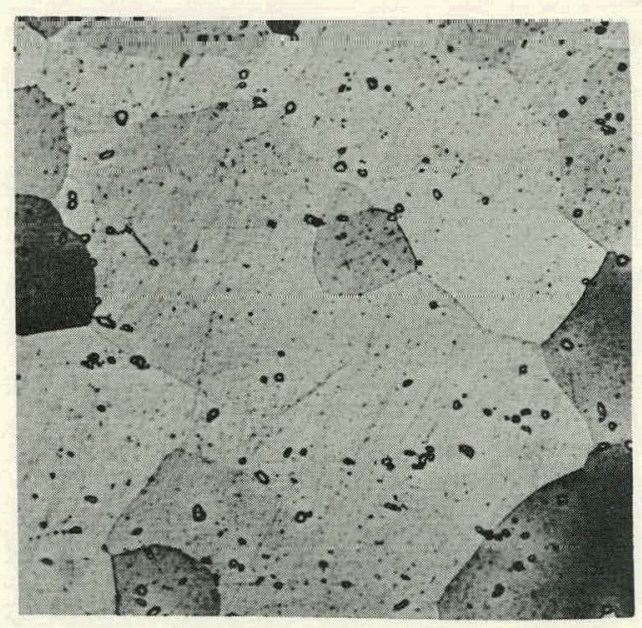

$900^{\circ} \mathrm{C} ; 500 \mathrm{X}$

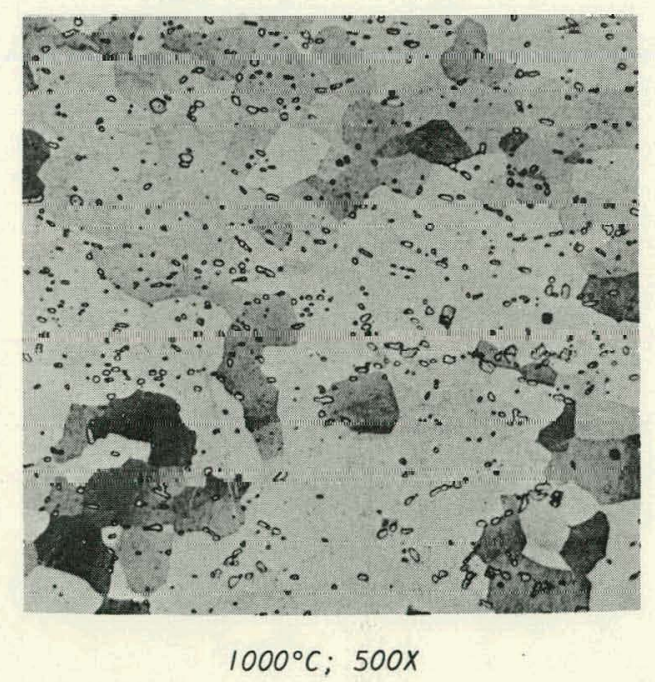

Fig. 38 Typical Microstructures of Quenched Zirconium +60 w/o Uranium Alloys 